\title{
Effect of interface-active proteins on the salt crystal size in waterborne hybrid materials
}

\author{
Stephani Stamboroski ${ }^{1,2,6^{*}} \mathbb{D}$, Kwasi Boateng ${ }^{1,2}$, Welchy Leite Cavalcanti ${ }^{1}$, Michael Noeske ${ }^{1}$, \\ Vinicius Carrillo Beber ${ }^{1}$, Karsten Thiel ${ }^{1}$, Ingo Grunwald ${ }^{3,4}$, Peter Schiffels ${ }^{1}$, Stefan Dieckhoff ${ }^{1}$ and \\ Dorothea Brüggemann ${ }^{2,5}$
}

\author{
*Correspondence: \\ stephani.stamboroski@ifam. \\ fraunhofer.de \\ ${ }^{6}$ Department Adhesion \\ and Interface Research, \\ Fraunhofer Institute \\ for Manufacturing \\ Technology and Advanced \\ Materials, Wiener Straße 12, \\ 28359 Bremen, Germany \\ Full list of author information \\ is available at the end of the
} article

\begin{abstract}
Aqueous processes yielding hybrid or composite materials are widespread in natural environments and their control is fundamental for a multiplicity of living organisms. Their design and in vitro engineering require knowledge about the spatiotemporal evolution of the interactions between the involved liquid and solid phases and, especially, the interphases governing the development of adhesion during solidification. The present study illustrates the effects of distinct proteins on the precipitation of sodium chloride encompassing the size, shape and distribution of halite crystals formed during the drying of droplets containing equally concentrated saline protein solutions. The precipitates obtained from aqueous sodium chloride formulations buffered with tris(hydroxymethyl)aminomethane (Tris) contained either bovine serum albumin (BSA), fibrinogen or collagen and were characterized with respect to their structure and composition using optical and electron microscopy as well as $x$-ray analysis. The acquired findings highlight that depending on the protein type present during droplet drying the halite deposits predominantly exhibit cubic or polycrystalline dendritic structures. Based on the phenomenological findings, it is suggested that the formation of the interphase between the growing salt phase and the highly viscous saline aqueous jelly phase containing protein governs not only the material transport in the liquid but also the material exchange between the solid and liquid phases.
\end{abstract}

Keywords: Protein-based composites, Sodium chloride, Bovine serum albumin, Collagen, Fibrinogen, Crystallization, Spatiotemporal development of adhesion, Damköhler number

\section{Introduction}

Natural hybrid or composite materials that are composed in aqueous environments and consist of organic and inorganic components or constituents are highly visible and frequent. Seashells, nacre, and bone are protein-based composite materials known for their high functionality at low weight, and their remains from geological eras long ago still shape the landscape in many regions of the world [1]. Moreover, understanding biomineralization processes and characterizing the properties of biomineralized organic/ inorganic hybrid materials provide inspiration for materials development following biomimetic principles [2].

c) The Author(s), 2021. Open Access This article is licensed under a Creative Commons Attribution 4.0 International License, which permits use, sharing, adaptation, distribution and reproduction in any medium or format, as long as you give appropriate credit to the original author(s) and the source, provide a link to the Creative Commons licence, and indicate if changes were made. The images or other third party material in this article are included in the article's Creative Commons licence, unless indicated otherwise in a credit line to the material. If material is not included in the article's Creative Commons licence and your intended use is not permitted by statutory regulation or exceeds the permitted use, you will need to obtain permission directly from the copyright holder. To view a copy of this licence, visit http:// creativecommons.org/licenses/by/4.0/. 
Protein-based composite materials with multi-level hierarchical structures and manifold functions form the basis of many living organisms [3]. Studies of prokaryotes, probably the oldest life-form on Earth, reveal that biomineralization is found in halophiles living in environments governed by high $\mathrm{pH}$ and high salt concentrations [4]. These extremophiles are able to attach ions to their outer surface to form minerals [5, 6]. This ability is attributed to a two-dimensional protein assembly, the so-called S-layer (surface layer) of such bacteria and archaea [5]. While the vast majority of biominerals found on Earth are inorganic compounds with oxoanions like carbonates, silicates or phosphates, the crystallization of the evaporite mineral halite, which is based on sodium chloride, is reportedly influenced by the presence of organic entities. These entities include, synthetically produced nanoparticles proposed as an analog to protocellular material [7], surface layers of Haloarcula strain SP8807 or the presence of halobacteria [8], the synthetic peptide ATEA [9], and also gelatin [10, 11]. The crystallization of calcium oxalate or phosphate salts during urolithogenesis in urine or in vitro may be influenced by both dissolved salts and the presence of proteins that contribute to the organic matrix of urinary stones up to several millimeters in width $[12,13]$. Hence, in addition to illustrating the effect of organic compounds on salt crystallization, the reciprocal effect of salts on the solidification of organic materials can be highlighted. For example, many proteins precipitate in the presence of highly concentrated salt solutions, like sodium chloride. This effect is known as salting out and its distinctness is reflected by the position of the salt-forming ions in the Hofmeister series [14], which elucidate the tendency of proteins to form aggregates in the presence of different ions [15]. Sodium chloride has also been reported to govern the solubility of lysozyme, $\alpha$-chymotrypsin and BSA [16]; drive the nucleation and the polymorphic transformation of the amino acid glycine [17]; influence specific attractive interactions relevant for the crystallization and precipitation behaviour of proteins like lysozyme [18]; and affect the aggregation of pork myofibrillar protein [19]. Moreover, sodium chloride can influence the tendency of proteins to hierarchically assemble into superstructures like fibers, such as with spider silk protein [20], the extracellular matrix protein collagen [21], and the blood plasma protein fibrinogen [22]. Submicroscopic protein crystals based on dense aggregates of macromolecular protein units were found in equine chondrocyte cells [23], and, nanoparticulate or crystalline structures composed of proteins and carbohydrates, and containing traces of metals like $\mathrm{Na}, \mathrm{K}, \mathrm{Mg}, \mathrm{Ca}, \mathrm{Al}$, and Si were identified in secretions [24].

Notably, the development of adhesion during natural processes occurring at dynamic interphases around solids is in the focus of a growing research area. Acquiring knowledge relating to anti-freeze proteins (AFP) [25, 26] or peptide-based bioadhesives [27] in terms of composition, structural design, and interaction with surfaces is essential for the implementation of underlying concepts based on biochemical and mechanical principles in trendsetting medical and technical applications [28, 29]. In the view of adhesion research, solid formation from an originally continuous fluid phase is an essential scenario during physical hardening [30] and even chemical curing [31]. Rätzke et al. highlighted that a causal sequence of process steps following nucleation and growth may start from sites governing the formation of interphases between the fluid and hardened phases [31]. These locally developing interphases may be perceived as the centerpiece of growth around centers. In these boundary regions, a balance evolves between 
the arrangement of material entities upon solid formation and the transport of entities towards the shifting solid/fluid interface [31]. The ratio between the reaction or incorporation flux and the mass transport flux can be represented by the Damköhler number (Da), which correlates transport phenomena, e.g. based on solutes, with time-dependent reaction rates [32] and facilitates the assessment of spatiotemporal distribution of the reaction rate under local non-equilibrium conditions as observed in precipitation/dissolution processes [33]. For $\mathrm{NaCl}$ precipitation from an aqueous solution during water evaporation, the Damköhler number was, for instance, shown to drastically change when the growth of sodium chloride crystals was observed [34]. Desarnaud et al. recently highlighted that in nature crystals are rarely found only in their equilibrium state [35]. Rather, many minerals and salts, like notably calcite and halite, form hopper crystals composed of clusters of interconnected crystalline regions. These authors point out that little fundamental work had been done on understanding hopper crystal shapes resulting from an anisotropic growth that is due to the edges of a crystal growing faster than the centers of its faces. With kinetics of growth being an important factor in determining the overall shape of a solid, a transition between cubic and hopper growth at a high supersaturation of around 1.5 was reported when the growth rate of the cubic crystal reached a maximum of around $7 \mu \mathrm{m} / \mathrm{s}$ [35]. Goto et al. presented dendritic morphologies of sodium chloride when grown in a thin gelatin gel matrix in which the mass transport is governed by diffusion. Furthermore, the authors demonstrated a significant influence of the [salt]/[gelatin] concentration ratio and the humidity around a drying aqueous solution on the halite crystal shape and growth velocity ranging from approximately 1 to $20 \mu \mathrm{m} / \mathrm{s}$ [11]. Choudhury et al. used a simple simulation algorithm incorporating aggregation and evaporation to reproduce the observed well-defined cross-over from a compact $\mathrm{NaCl}$ crystal morphology in aqueous gelatin to a dendritic pattern as water evaporation proceeded [10]. Lately, Yang et al. [36] reviewed self-assembly in hopper-shaped crystals and described the change of crystal morphology according to a change of the interfacial instability. They established the role of capping agents that may inhibit the adsorption of a newly added building block on the surface of a growing solid. With respect to crystalline evaporative deposition, McBride et al. [37] showed that the energetics between all the three phases involved in the crystallization of solutes, namely substrate, crystal, and liquid, contribute to the nucleation barrier, and the authors elucidated that salt solutions with lower nucleation barriers will pin-drop substrate/drop contact lines to form rings.

Based on these studies and recent reports [38], it becomes clear that exploiting the mutual influences between proteins and salts for material design is an approach that is gaining increasing technological relevance. Thus, it is important to gain a fundamental understanding of the protein/salt or peptide/salt interactions when solid materials are formed from an aqueous phase. Such knowledge on liquid-solid transitions in the presence of different salts will be of great relevance for controlling the formation and multifunctional properties of new protein-based composite materials. In natural and biotechnical processes, the respective solid formation often starts from a liquid formulation comprising a solvent, an inorganic solute, and an organic co-solute and proceeds via the formation of growth units [11] as relevant entities, their assembly into nuclei, and the growth of metastable or stable solid phases [17]. Alternatively, processes allocating 
inorganic and organic moieties from different formulations may be engineered, e.g. using layer-by-layer [39] or sol-gel processes [40]. Recently, within the scope of tailoring biomimetic hybrid collagen/chitosan hydrogels with a dual network structure [38], an immersion in a highly concentrated $5 \mathrm{wt} \%$ aqueous sodium sulfate solution was reported to result in an opaque gel during a universal soaking step following a UV-induced crosslinking step.

Based on knowledge from experimental or simulation approaches, target-oriented strategies can be framed not only for the synthesis of bio-inspired materials, e.g. nacrelike composites [41], or surfactants for interface engineering [42, 43], but also for assessing environmental, agricultural, alimentary, medical or pharmaceutical challenges [17, $19,38,42,44-46$ ], e.g. avoiding the formation of renal stones [44]. Systematic material development is significantly promoted by applying scale-comprehensive simulation, e.g. of growth processes [30, 47], and access to databases facilitated by data and metadata interoperability [48].

Lately, our group demonstrated how salt-driven self-assembly can be applied for the physiological preparation of nanofibrous fibrinogen scaffolds to support cell adhesion [49-51] and compared relevant approaches for fibrinogen fiber assembly in vitro [22]. By precipitating a water-soluble mixture of salts in the presence of fibrinogen, the salts enabled the formation of dense nanofiber networks upon drying. On the other hand, chloride salts of calcium, magnesium, copper and zinc hamper fibrinogen fiber formation [52]. Moreover, we routinely used highly concentrated salt solutions to assemble the extracellular matrix protein collagen into nanofibers to control the growth of different cell types [53, 54]. In view of the hierarchy for hybrid materials presented by Saveleva et al. [55], such self-assembly processes start from an organic molecule-modified inorganic material (organics-in-inorganics) and end with a potentially inorganic-modified organic material (inorganics-in-organics). In the present contribution, we therefore focus on revealing the interface-active action of the proteins BSA, fibrinogen and collagen type I in the organics-in-inorganics approach for directing the crystallization of the alkali metal salt sodium chloride upon drying protein-containing saline water. While BSA and fibrinogen are both blood plasma proteins, collagen contributes to the assembly of an extracellular matrix during the early stages of wound healing [56]. In detail, we present microscopic images for evaluating the crystal size distribution and energy dispersive $\mathrm{x}$-ray analysis (EDX) studies for disclosing the presence of an organic surface film.

\section{Materials and experimental procedure}

\section{Sample preparation}

All solutions were prepared using ultrapure water from a TKA water purification system (Thermo Fisher Scientific, Schwerte, Germany). A sufficient amount of tris(hydroxymethyl)aminomethane (Tris, $\mathrm{C}_{4} \mathrm{H}_{11} \mathrm{NO}_{3}$, Carl Roth GmbH, Karlsruhe, Germany) to obtain a $10 \mathrm{mM}$ concentration was dissolved in ultrapure water and the $\mathrm{pH}$ of the solution was adjusted to 7.4 with hydrochloric acid (aqueous $\mathrm{HCl}$, VWR, Darmstadt, Germany). Likewise, sodium chloride ( $\mathrm{NaCl}$, VWR) was dissolved in the Tris$\mathrm{HCl}$ buffer to obtain a stock solution concentration of $1.5 \mathrm{M}$. Fibrinogen stock solutions were prepared by dissolving $10 \mathrm{mg} / \mathrm{mL}$ fibrinogen (100\% clottable, Merck, Darmstadt, 
Germany) in a $10 \mathrm{mM}$ Tris $-\mathrm{HCl}$ solution. The fibrinogen stock solution was dialyzed against a $10 \mathrm{mM}$ Tris- $\mathrm{HCl}$ solution overnight using cellulose membrane dialysis tubing with $14 \mathrm{kDa}$ cut-off (Sigma, Steinheim, Germany) to remove low molecular weight compounds. The BSA stock solution was prepared by dissolving $10 \mathrm{mg} / \mathrm{mL}$ BSA (Sigma Aldrich Munich, Germany) in $10 \mathrm{mM}$ Tris- $\mathrm{HCl}$ buffer. Collagen stock solutions were prepared by dissolving $10 \mathrm{mg} / \mathrm{mL}$ collagen type I from calf skin (Sigma Aldrich, Munich, Germany) in 5\% aqueous acetic acid (Carl Roth GmbH, Karlsruhe, Germany). Round glass coverslips with a diameter of $12 \mathrm{~mm}$ (VWR, Darmstadt, Germany) were sputtercoated with a $5 \mathrm{~nm}$ thin adhesion layer of chrome, followed by $25 \mathrm{~nm}$ of gold, using an EM ACE600 high vacuum sputter coater (Leica Microsystems, Wetzlar, Germany). A volume of $70 \mu \mathrm{L}$ of the respective protein solution was pipetted onto the gold-coated glass substrates, followed by the addition of $70 \mu \mathrm{L}$ salt solution to the protein drop. For the preparation of samples without protein, $70 \mu \mathrm{L}$ of the salt solution was pipetted onto the gold-coated glass followed by $70 \mu \mathrm{L}$ of ultra-pure water to adjust the salt and Tris$\mathrm{HCl}$ concentrations. The samples were placed in a container purged with dry $\mathrm{N}_{2}$ gas, and after the droplet drying process the samples were transferred to a home-built humidity chamber to be incubated at $24^{\circ} \mathrm{C}$ and $30 \%$ relative humidity overnight.

\section{Microscopic surface analysis}

All optical microscopy images were obtained with a Keyence VHX-7000 digital microscope (Keyence, Neu-Isenburg, Germany). The samples were imaged in overall survey applying stitching and using magnification from $20 \times$ for single partial images. Details of the precipitated salt or the protein deposits were imaged with magnifications varying from $80 \times$ to $500 \times$. Moreover, after depositing a thin electrically conductive carbon layer more detailed inspection was performed with Scanning Electron Microscopy (SEM) using a field emission device (FESEM), type FEI Helios 600 (Dual Beam, FEI, Eindhoven, Netherlands). The resolution was $0.9 \mathrm{~nm}$ at $15 \mathrm{kV}$ at optimal working distance and $1 \mathrm{~nm}$ at $15 \mathrm{kV}$ at the coincidence point. The images of the sample surface were obtained at acceleration voltages between 0.35 and $30 \mathrm{kV}$ and at working distances between 1 and

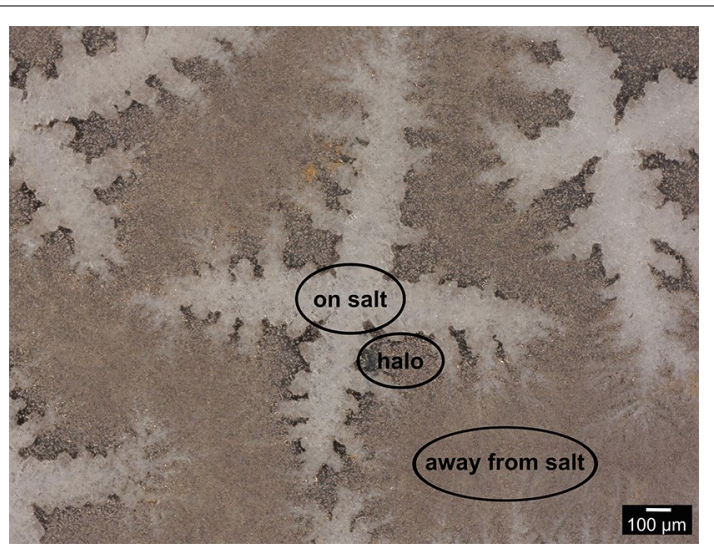

Fig. 1 Light microscopy image of deposits containing $\mathrm{NaCl}$, fibrinogen and Tris moieties. Introduction of the terminology applied for surface areas imaged with higher magnification and SEM analysis: the surface of apparently crystalline salt deposits (labelled "on salt"), the halo close to the salt deposits (labelled "halo"), and regions beyond the halo (labelled "away from salt") 


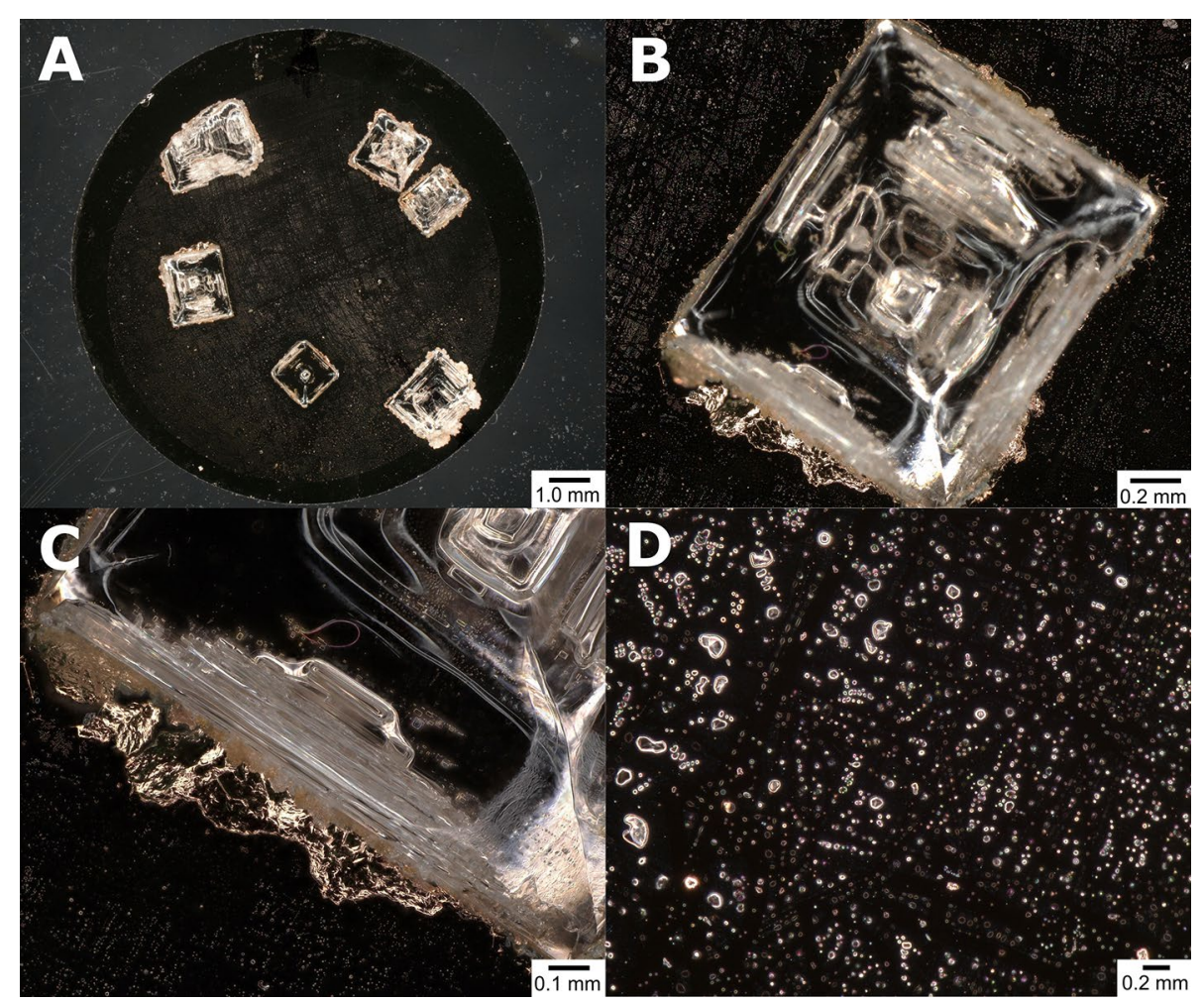

Fig. 2 Light microscopy images of $\mathrm{NaCl}$ crystals formed after drying a droplet of a solution containing $375 \mathrm{mM} \mathrm{NaCl}$ and $5 \mathrm{mM}$ Tris-HCl buffer. (A) Overview image of the sample ( $\times 20$ magnification), (B) selected $\mathrm{NaCl}$ crystal ( $\times 80$ magnification), (C) detail of a top-sided edge of the selected crystal ( $\times 200$ magnification) and (D) detail of deposits found away from the tabular crystals on the substrate surface ( $\times 500$ magnification)

$10 \mathrm{~mm}$. For the detection of secondary or backscattered primary electrons an EverhartThornley or an in-lens detector was used.

\section{EDX investigations}

EDX measurements were performed with the same FESEM of type FEI Helios 600 (DualBeam) equipped with an Oxford X-Max80 silicon drift detector (SDD) for x-rays, an ATW2-window and an energy resolution down to $129 \mathrm{eV}$. The detection angle of the detector was $52^{\circ}$.

\section{Results and discussion}

The following discusses, the structure and arrangement of the $\mathrm{NaCl}$ crystals formed upon droplet drying as well as the composition of the deposits revealed in their surroundings. Hereby, the results of four scenarios are considered; namely the deposits resulting from water evaporation from Tris- $\mathrm{HCl}$ buffered aqueous formulations free of biopolymers in comparison with those obtained in the presence of BSA, fibrinogen or collagen, respectively. The Tris- $\mathrm{HCl}$ buffer was used to maintain the same physiological $\mathrm{pH}$ (7.4) for all four starting formulations involved in this study. In detail, three characteristic regional sections within the laterally inhomogeneous drying patterns were considered, as displayed in Fig. 1; these comprise the surface of apparently crystalline salt 


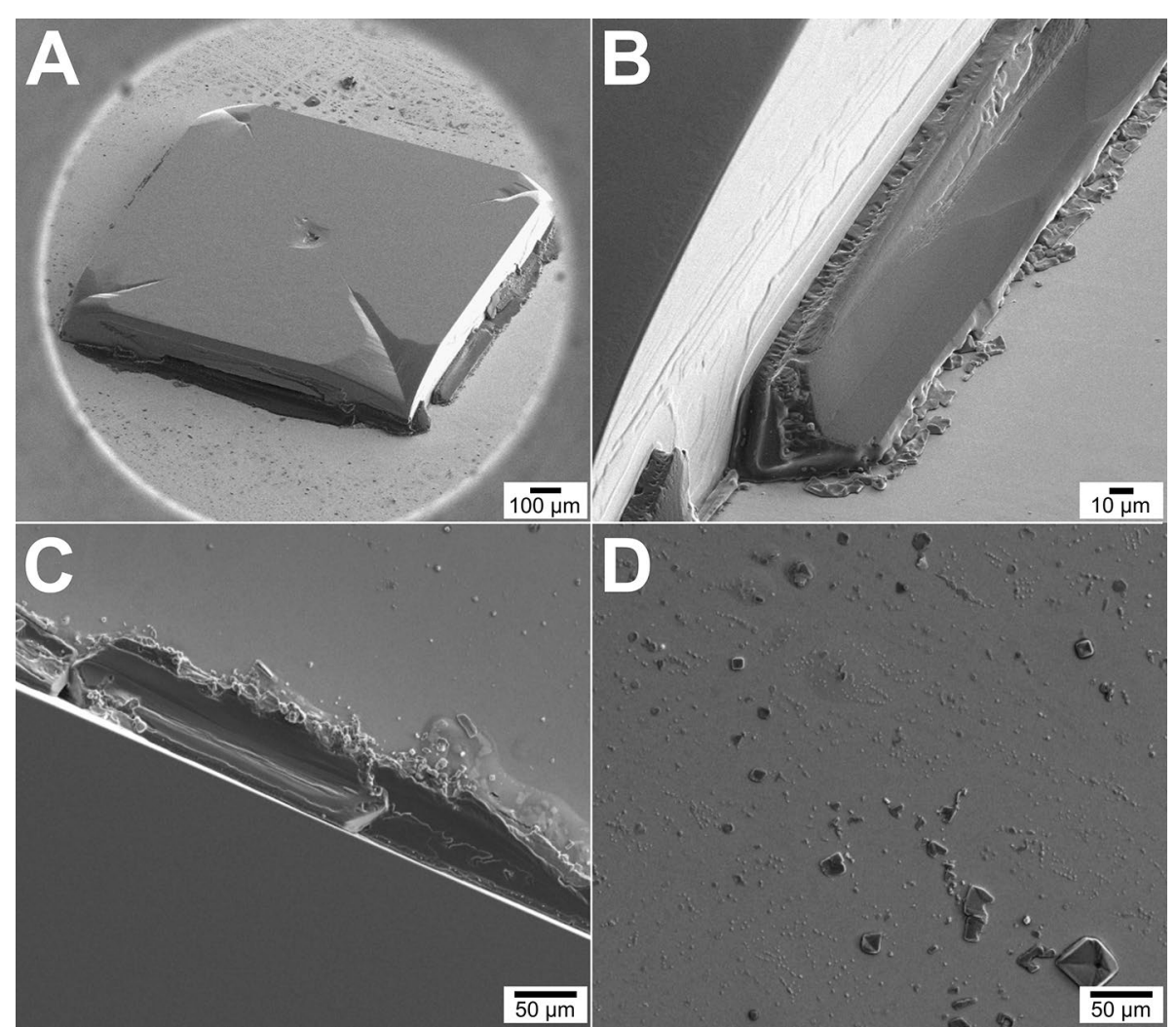

Fig. 3 SEM images of $\mathrm{NaCl}$ crystals formed after drying a droplet of a solution containing $375 \mathrm{mM} \mathrm{NaCl}$ and $5 \mathrm{mM}$ Tris-HCl buffer. (A), (B) Show the SE-SEM images of an $\mathrm{NaCl}$ crystal and its halo region, respectively. (C) Displays the surface (bottom left) and halo regions (top right) of a salt crystal while (D) depicts the substrate area away from any $\mathrm{NaCl}$ crystals

deposits (called "on salt"), the halo close to the salt deposits (called "halo"), and regions beyond the halo (called "away from salt").

\section{Macrostructure variation of $\mathrm{NaCl}$ crystals precipitated in the absence of proteins}

After sodium chloride was dried in the absence of proteins the precipitated $\mathrm{NaCl}$ crystals were imaged with light microscopy and SEM. Figure 2 depicts the top view light microscopy images obtained after drying a droplet that was initially about $2 \mathrm{~mm}$ narrower than the substrate slide, as can be inferred from the approx. $1 \mathrm{~mm}$ wide dark rim shown in the light microscopic image in Fig. 2A. Water evaporation occurring over the course of two hours gave rise to the formation of six $\mathrm{NaCl}$ crystals with a rectangular, almost square base. While the width of these crystals varied between 1.3 and $2.5 \mathrm{~mm}$, the heights of up to $0.2 \mathrm{~mm}$ were approximately one order of magnitude smaller. The tabular shape of the $\mathrm{NaCl}$ crystals was confirmed by the SEM in Fig. 3A, which illustrates that the crystal plateau height does not exceed the droplet height. Most of these crystals exhibited one edge that was less than $1 \mathrm{~mm}$ away from the initial contact line and the central substrate region was free from such distinct salt crystals. This finding can be explained by the observation that the decline of the liquid volume primarily resulted in a reduction of the droplet height rather than the droplet width. Details of the surface and the 


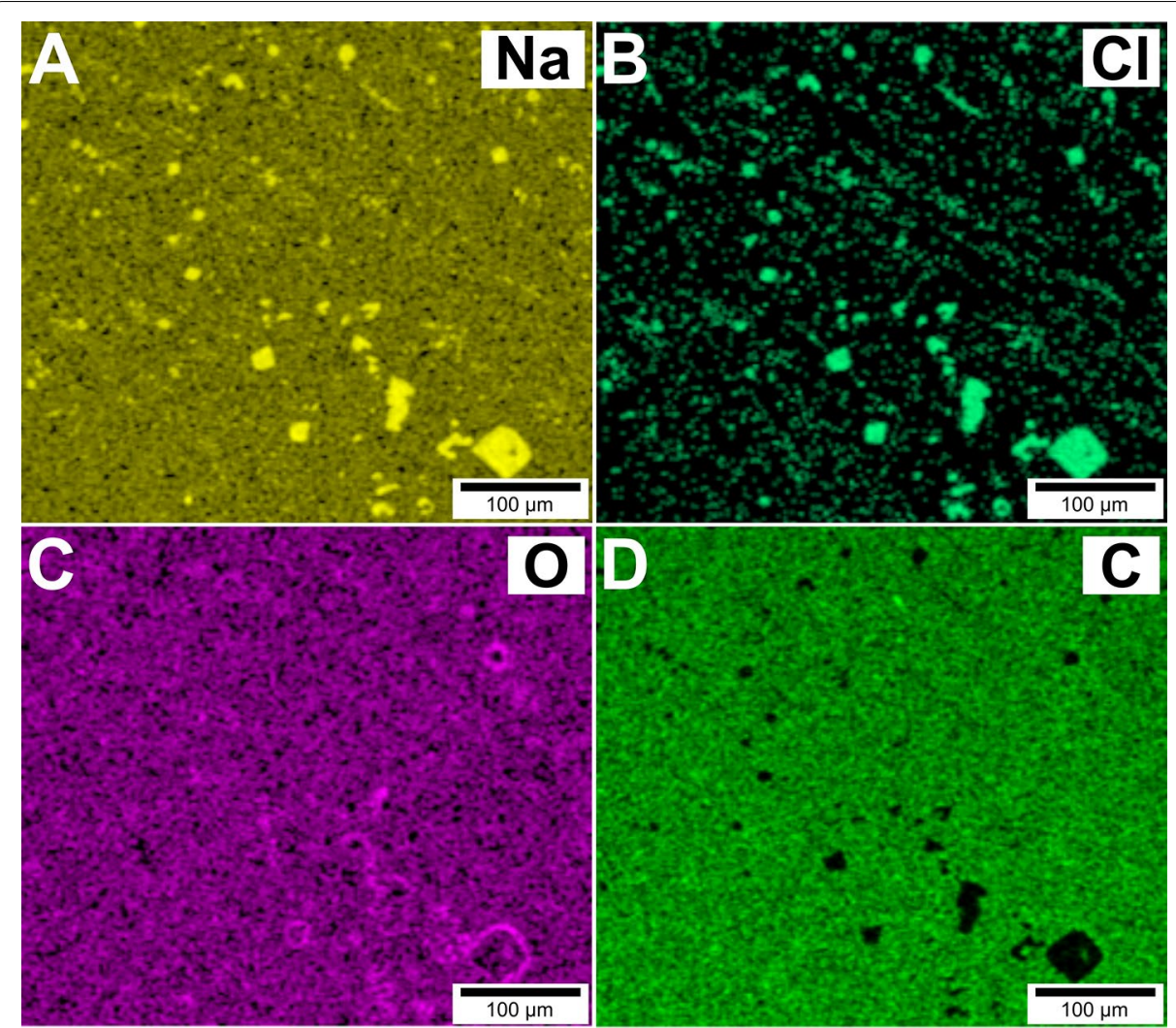

Fig. 4 EDX map false color representations of the substrate surface "away from salt", as shown in Fig. 3D obtained after drying a droplet of a solution containing $375 \mathrm{mM}$ of $\mathrm{NaCl}$ and $5 \mathrm{mM}$ Tris-HCl buffer: Na map (A), Cl map (B), O map (C), and C map (D)

shape of a 3D crystal can be seen in Fig. 2B, C. The crystal growth seemed to be faster at the crystal edges than at the crystal center or corners since steps and depressions were observed in the central region and at the corners of the crystals. The basal corners of the crystals show $90^{\circ}$ angles, as expected for the growth morphology of halite, yet the topmost corners were not complete and exposed unfilled steps. In regions between the bigger crystals, and notably around the sample center, deposits of tiny $\mathrm{NaCl}$ crystals up to $30 \mu \mathrm{m}$ in width can be observed as suggested by the light microscopy (see Fig. 2D) and SEM analyses (see Fig. 3D) and substantiated by the element contrast revealed in the EDX maps highlighting locally elevated $\mathrm{Na}$ and $\mathrm{Cl}$ concentrations (Fig. 4A, B). The bases of the halite crystals are bordered by amorphous deposits that are comparatively poor in $\mathrm{Na}$ or $\mathrm{Cl}$ species but rich in $\mathrm{O}$ and $\mathrm{C}$ containing moieties based on the contrast in the EDX maps shown in Figs. 4 and 5. Due to this elemental composition, these deposits can be attributed to solid Tris moieties.

As Tris-based deposits were observed and as they revealed a laterally inhomogeneous distribution we infer that Tris constitutes not only a buffer but also a co-solute of sodium chloride. Moreover, Taha et al. reported interactions between $\mathrm{Na}^{+}$and $\mathrm{Cl}^{-}$ions and Tris 


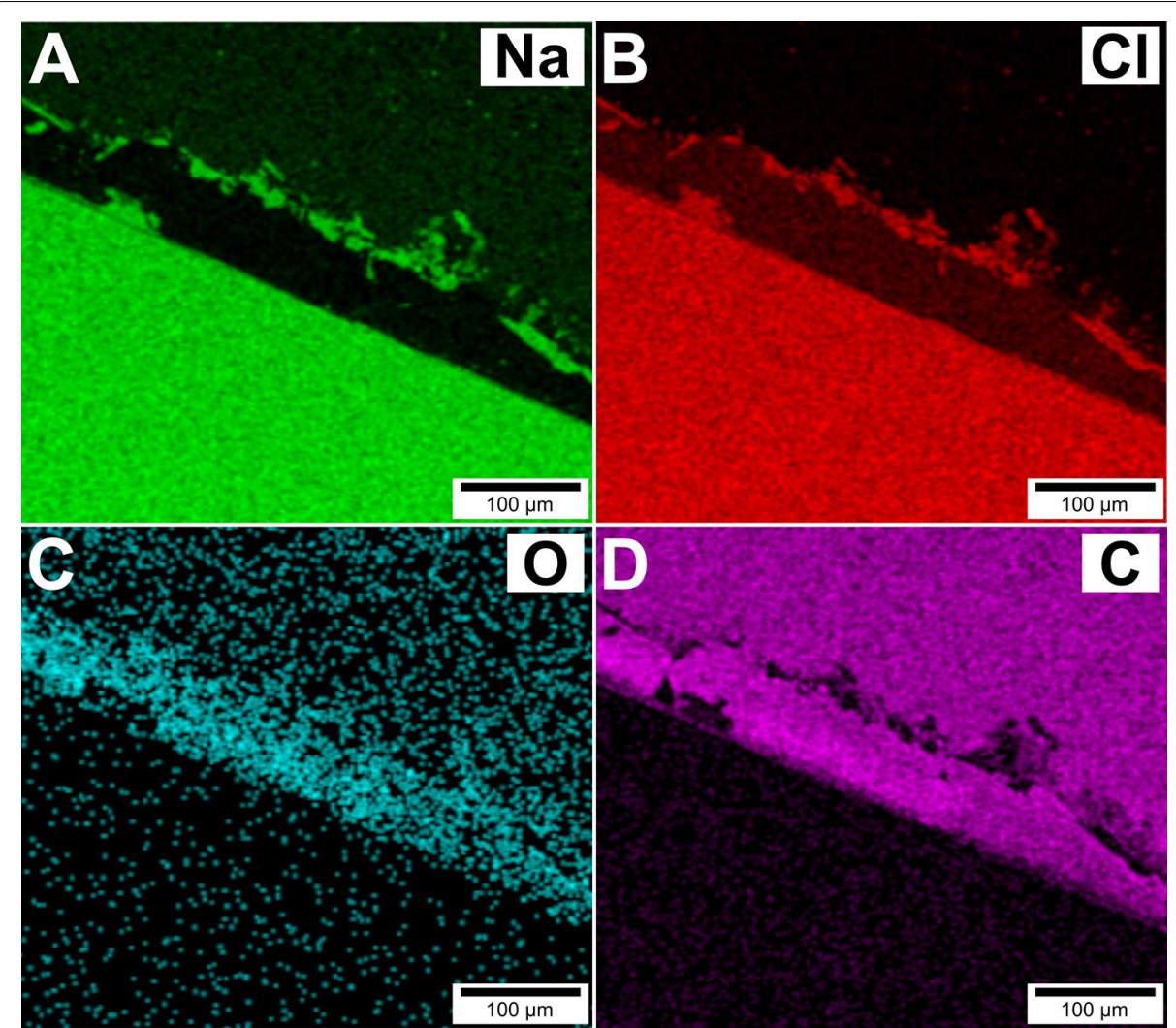

Fig. 5 EDX map false color representations of the surface (bottom left) and halo regions (top right) in the same region as shown in Fig. $3 \mathrm{C}$ for a $\mathrm{NaCl}$ crystal formed after drying a droplet of a solution containing $375 \mathrm{mM}$ of $\mathrm{NaCl}$ and $5 \mathrm{mM}$ tris-HCl buffer: $\mathrm{Na}$ map (A), Cl map (B), O map (C), and C map (D)

molecules [57]. The crystallization-related effects of the interactions between Tris, salt and water at interfaces are subject to ongoing studies.

\section{Macrostructure variation of $\mathrm{NaCl}$ crystals precipitated in the presence of proteins}

The following sections highlight the effects resulting from the presence of the proteins BSA, fibrinogen or collagen on the structure of sodium chloride precipitates as well as the arrangement and composition of organic deposits.

\section{Effect of BSA}

When $5 \mathrm{mg} / \mathrm{mL}$ BSA as a starting concentration was adjusted in the solution left for drying, seven bigger $\mathrm{NaCl}$ crystals with widths varying from 1 to $1.8 \mathrm{~mm}$ and a rectangular base were observed (Figs. $6 \mathrm{~A}$ and $7 \mathrm{~A}$ ), similar to the salt precipitates obtained after drying the droplet without any protein. Similarly to Figs. $2 \mathrm{~B}, \mathrm{C}$ and $6 \mathrm{~B}, \mathrm{C}$ show more surface topography details of the central $\mathrm{NaCl}$ crystal. Figure $6 \mathrm{D}$, in particular, shows the formation of more tiny crystals and dendrite growth from the edges towards the center of the substrate. However, the crystal shape formed in the presence of BSA was significantly different from $\mathrm{NaCl}$ deposits formed in the absence of protein since the bigger halite crystals were hoppered. In contrast, numerous arrangements of dendritic $\mathrm{NaCl}$ crystallites were found in regions away 


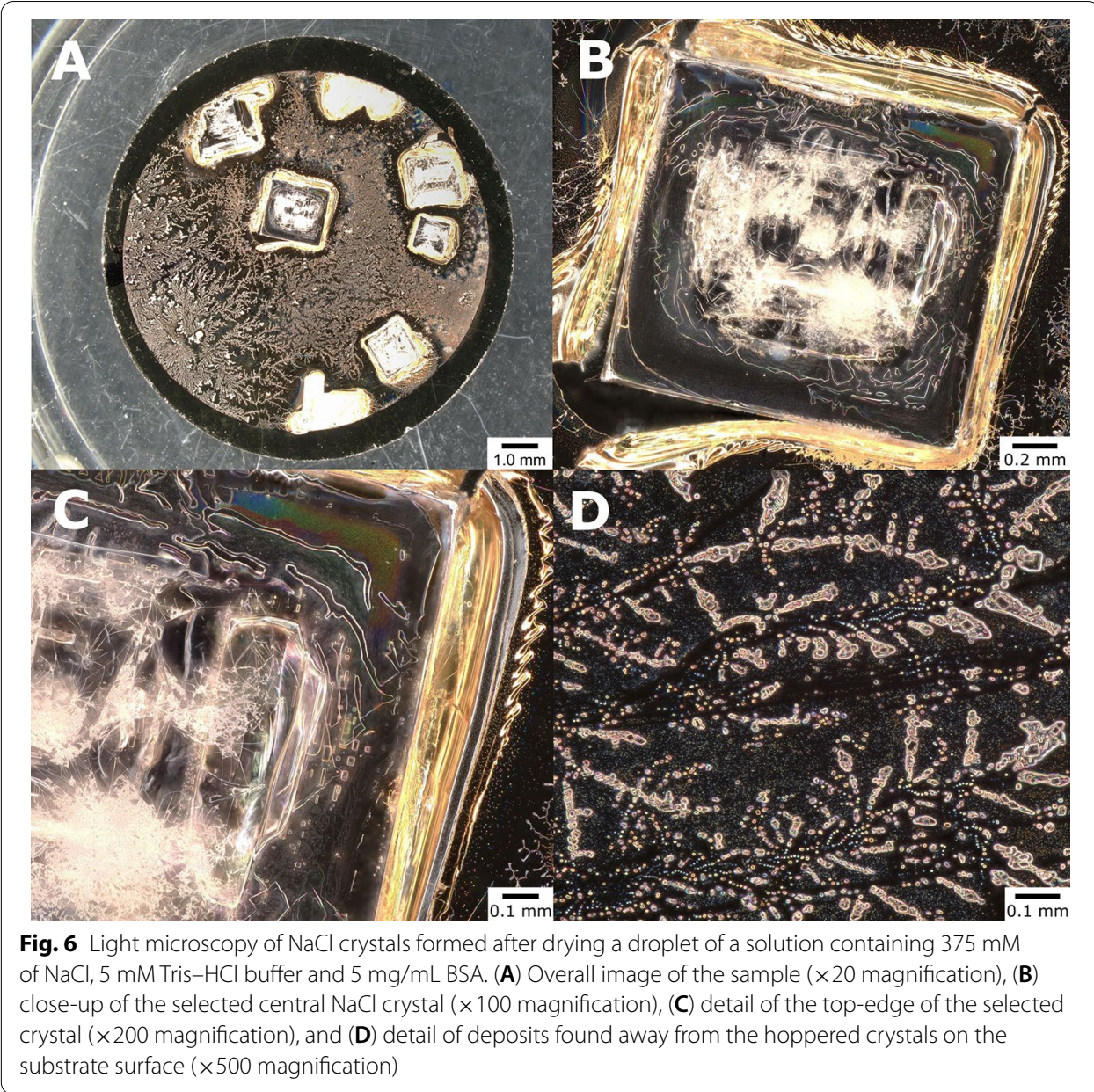

from salt (see Figs. 6D and 7B-D), with their sizes varying between approximately 1 and $100 \mu \mathrm{m}$. This finding indicates that the nucleation of salt crystals is not a limiting step within a nucleation and growth scenario. Rather, the observed multiplicity of small crystallites is attributed to a hindered transport of $\mathrm{NaCl}$ growth units in the BSA-containing fluid and, therefore, the dendrite formation may be inferred to occur in a later stage of the droplet drying than the growth of huge hoppered halite crystals. As such prevalence of salt dendrites was not observed upon the drying of protein-free droplets, we suggest that in this ultimate drying stage the viscosity of the remaining liquid was higher due to the presence of BSA and its self-assembly by the increase in salt concentration. Previously, similar aspects were addressed with respect to drying aqueous gelatin formulations resulting in a viscous gel film upon water evaporation $[10,58]$. Such a protein-related effect may be in addition to the effect experienced by the salt growth units through the successively increasing salt concentration upon water evaporation [59].

As revealed by light microscopy, SEM analysis and the EDX maps obtained from the surface of halite hoppers (cf. Figs. 6B, C and 8), the central hopper region acted 


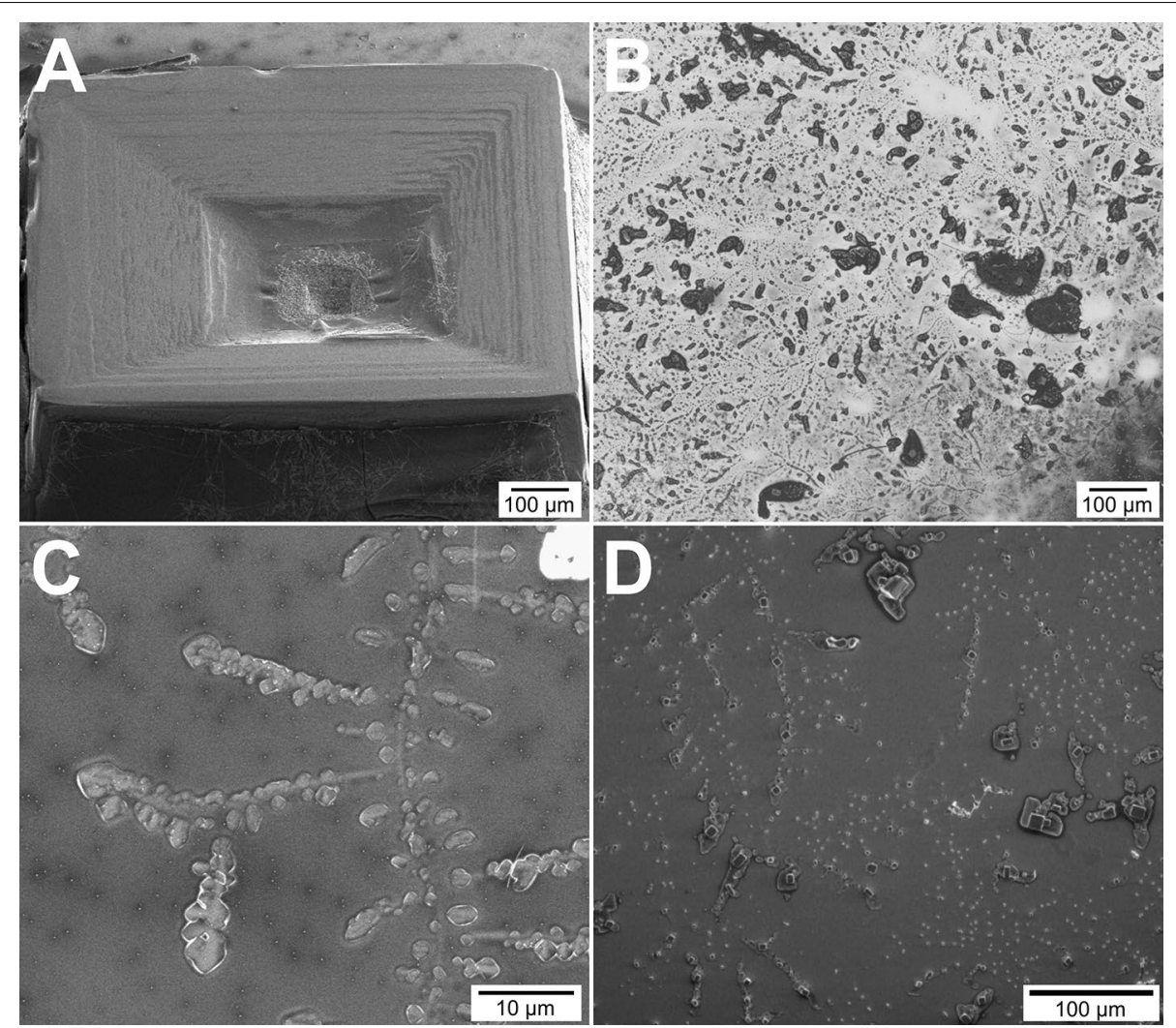

Fig. 7 SEM images obtained after drying a droplet of a solution containing $375 \mathrm{mM} \mathrm{NaCl}, 5 \mathrm{mM}$ Tris- $\mathrm{HCl}$ buffer and $5 \mathrm{mg} / \mathrm{mL}$ BSA. (A) SE-SEM image of a hoppered NaCl crystal, (B) BSE-SEM image of a detail close to the halo of a NaCl crystal, (C) SE-SEM image obtained in the halo, and (D) overview image away from salt

as a pool for the remaining liquid during droplet drying. The thus provided microenvironment featured deposits that were dominated by Tris and its hydrochloride (Tris- $\mathrm{HCl}$ ), as can be concluded from the EDX findings listed in Table 1. In detail, the corresponding EDX maps not only showed a significant atomic concentration of chloride without revealing any metal cations but also revealed an $[\mathrm{N}] /[\mathrm{O}]$ concentration ratio around 0.45 , which is similar to the stoichiometrically expected ratio for Tris, i.e. $[\mathrm{N}] /[\mathrm{O}]=0.33$, or possibly mixtures resulting from interactions of Tris with BSA [60], which are expected to be closer to 1 in view of the predominant ratio of $[\mathrm{N}] /[\mathrm{O}]=1$ of the peptide groups in proteins. Moreover, the organic deposits visible via light microscopy and SEM seem to decorate and wrap the salt hoppers as well as the smaller crystallites around their borders (see Figs. 6B, 7B and 9C).

\section{Effect of fibrinogen}

When $5 \mathrm{mg} / \mathrm{mL}$ fibrinogen as a starting concentration was added to the $\mathrm{NaCl}$ solution and left to drying, no apparently single crystalline halite deposits more than $1 \mathrm{~mm}$ wide were observed. Rather, the original contact line was decorated by a rim of $\mathrm{NaCl}$ deposits less than $0.5 \mathrm{~mm}$ wide. Around the initial droplet center, a dozen crosswise salt dendrites with maximum lengths between 1 and $2 \mathrm{~mm}$ and maximum 


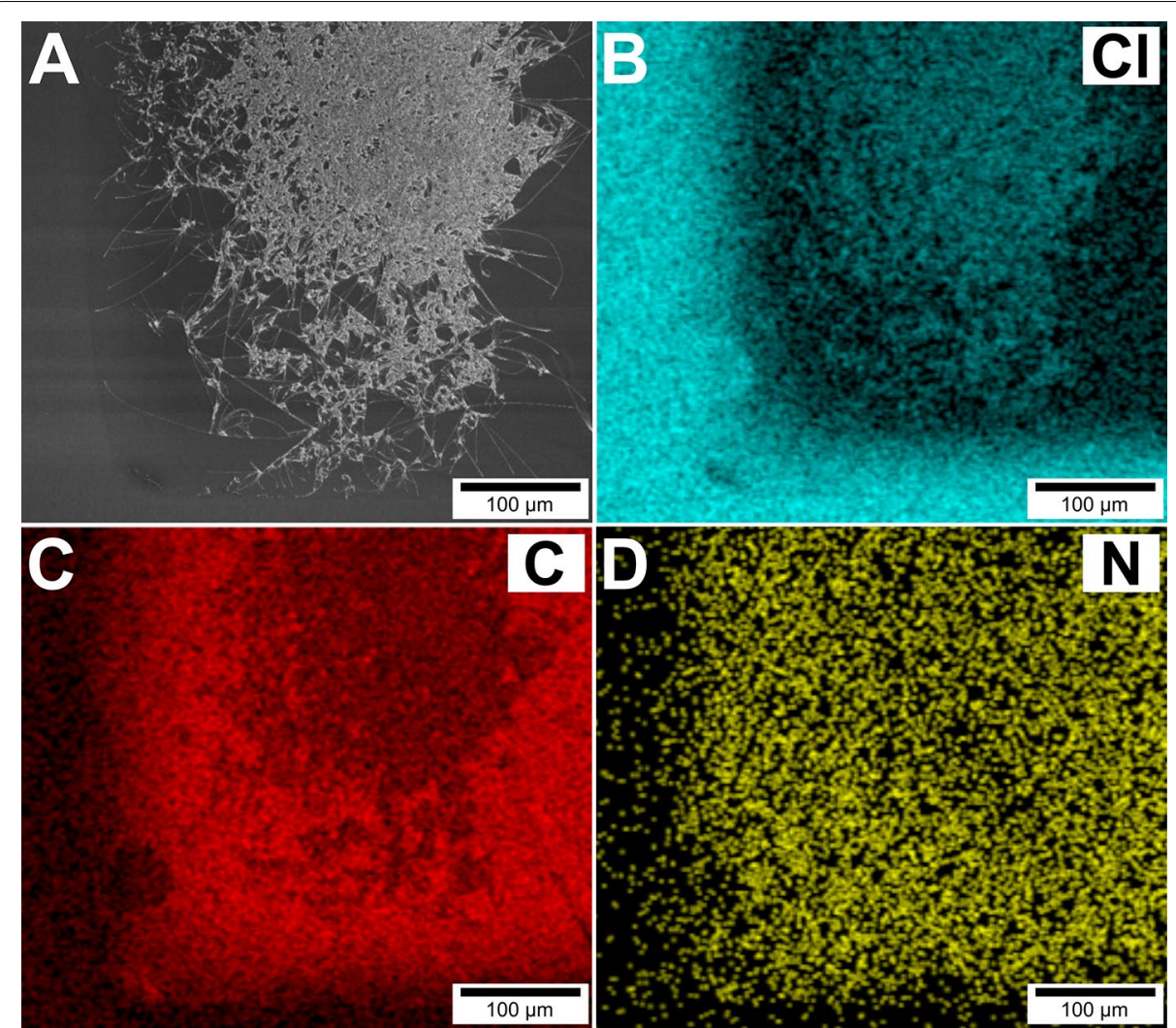

Fig. 8 SEM image and EDX map false color representations in the same region of the salt surface obtained after drying a droplet of a solution containing $375 \mathrm{mM} \mathrm{NaCl}, 5 \mathrm{mM}$ Tris-HCl buffer and $5 \mathrm{mg} / \mathrm{mL}$ BSA: (A) SEM image, (B) Cl map, (C) C map, and (D) N map

Table 1 Evaluation of the EDX investigations for distinct surface regions of deposits from $\mathrm{NaCl}$ with and without different proteins obtained from Tris-buffered droplets

\begin{tabular}{llllllll}
\hline Sample & [C] (at\%) & [N] (at\%) & [O] (at\%) & [Na] (at\%) & [Cl] (at\%) & [S] (at\%) & [N]/[O] \\
\hline $\begin{array}{l}\text { Surface of tabular NaCl crystal, } \\
\text { without protein (10 kV) }\end{array}$ & 21.1 & - & 0.3 & 40.2 & 38.4 & - & - \\
$\begin{array}{l}\text { Surface of hoppered NaCl crystal, } \\
\text { with BSA (10 kV) like in Fig. 8 }\end{array}$ & 56.2 & 12.2 & 27.0 & - & 4.6 & - & 0.45 \\
$\begin{array}{l}\text { Beading in halo of hoppered NaCl } \\
\text { crystal, with BSA (10 kV) }\end{array}$ & 57.7 & 18.5 & 23.3 & 0.3 & 0.9 & 0.3 & 0.79 \\
$\begin{array}{l}\text { Overall dendritic NaCl crystal and } \\
\text { halo, with fibrinogen (10 kV) }\end{array}$ & 61.6 & 6.5 & 7.1 & 12.9 & 11.7 & 0.1 & 0.92 \\
$\begin{array}{l}\text { Around center of dendritic NaCl } \\
\text { crystal, with fibrinogen (10 kV) }\end{array}$ & 53.7 & 3.6 & 2.9 & 20.2 & 19.4 & 0.1 & 1.2 \\
$\begin{array}{l}\text { Away from dendritic NaCl crystal, } \\
\text { with fibrinogen (10 kV) }\end{array}$ & 69.4 & 8.4 & 8.8 & 6.9 & 6.0 & 0.2 & 0.95 \\
$\begin{array}{l}\text { Overall dendritic NaCl crystal } \\
\text { and surrounding, with collagen } \\
\text { (10 kV) like in Fig. 14B }\end{array}$ & 59.8 & 12.1 & 22.4 & 2.5 & 3.2 & 0.05 & 0.54 \\
$\begin{array}{l}\text { Tris, according to stoichiometric } \\
\text { composition }\end{array}$ & 50 & 12.5 & 37.5 & - & - & & \\
\hline
\end{tabular}

The atomic concentrations (at\%) and the $[\mathrm{N}] /[\mathrm{O}]$ concentration ratio are given as obtained with an electron acceleration voltage of $10 \mathrm{kV}$ 


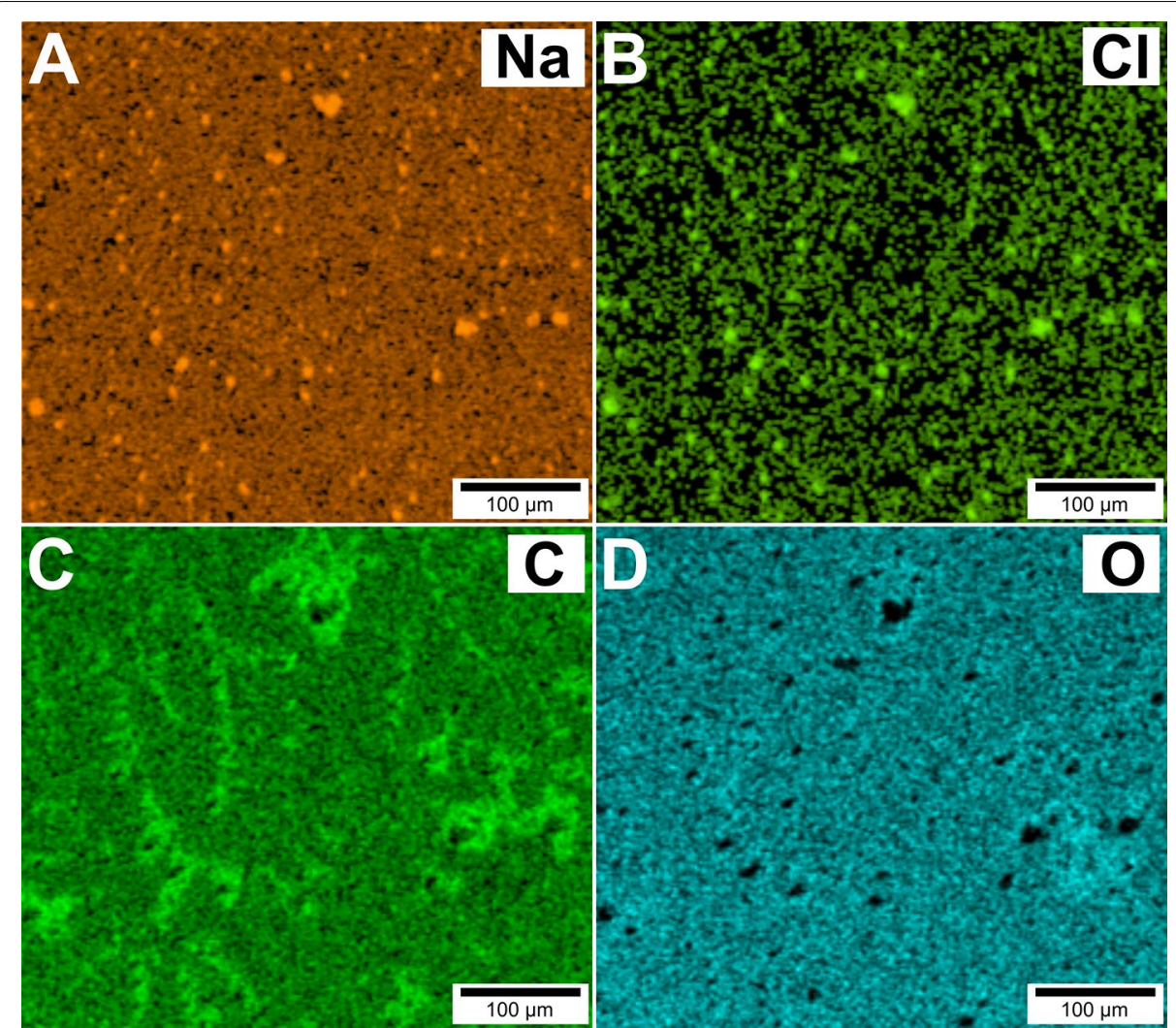

Fig. 9 EDX map false color representations in the region "away from salt" as displayed in Fig. 7D and obtained after drying a droplet of a solution containing $375 \mathrm{mM} \mathrm{NaCl}, 5 \mathrm{mM}$ Tris-HCl buffer and $5 \mathrm{mg} / \mathrm{mL}$ BSA: Na map (A), Cl map (B), C map (C), and O map (D)

widths between 0.2 and $0.3 \mathrm{~mm}$ were observed (see Fig. 10A). The compact packing within the manifestly polycrystalline dendritic $\mathrm{NaCl}$ deposits (see Fig. 11C) indicates that the heterogeneous nucleation of the up to several micrometer wide cubic grains on the surface took place, while the lateral growth stopped at the grain boundaries. The near-surface material contrast achieved by the detection of back-scattered electrons (BSE) as shown in Fig. 11B, C and the elemental distribution revealed by the EDX maps (see Fig. 12) recorded on top and around the intersection area of the two orthogonal branches constituting the crosswise $\mathrm{NaCl}$ dendrite revealed three distinct characteristics. First, the elevated regions of the salt deposits are covered by patches of an organic substance composed of elements with a lower atomic number than $\mathrm{Na}$ or $\mathrm{Cl}$. The findings from the EDX analysis listed in Table 1 reveal a significant attenuation of $\mathrm{Na}$ and $\mathrm{Cl}$ signals from the underlying sodium chloride and an $[\mathrm{N}] /[\mathrm{O}]$ atomic concentration ratio around 1 . Correspondingly, the organic deposits are interpreted to be predominantly composed of fibrinogen multilayers. Second, an approximately $100 \mu \mathrm{m}$ wide halo that is depleted in $\mathrm{NaCl}$ is visible close to the central intersection area of the crosswise dendritic crystals. Third, in comparison to the central dendrite regions, the lower extensions adjacent to the principal branch revealed a lower coverage by such organic moieties. 


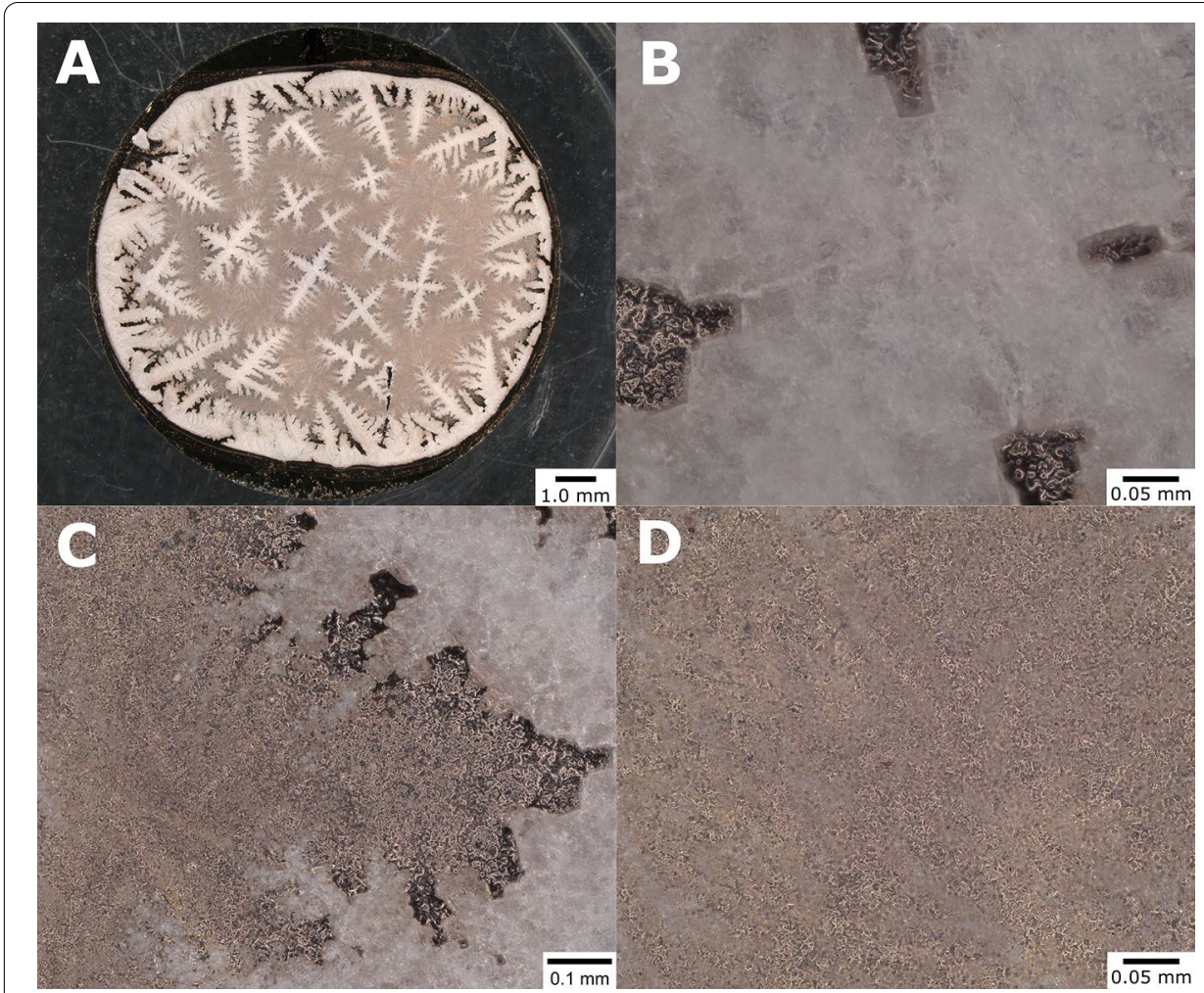

Fig. 10 Light microscopy of $\mathrm{NaCl}$ crystals formed after drying a droplet of a solution containing $375 \mathrm{mM}$ $\mathrm{NaCl}, 5 \mathrm{mM}$ Tris-HCl buffer and $5 \mathrm{mg} / \mathrm{mL}$ fibrinogen. (A) Overview image of the sample (×20 magnification), (B) detail on salt ( $\times 100$ magnification), (C) detail on the halo region ( $\times 200$ magnification) and (D) detail of deposits found away from the bigger crystals on the substrate surface ( $\times 500$ magnification)

Since we did not detect any noticeable X-ray emission from the underlying gold substrate we conclude that the respective $\mathrm{NaCl}$ moieties were deposited on top of an organic film. This film is thicker than that on top of the $\mathrm{NaCl}$ dendrites. Similar findings were obtained in regions away from the salt dendrites, as shown in Fig. 11D and in Table 1, which once again revealed an $[\mathrm{N}] /[\mathrm{O}]$ atomic concentration ratio of around 1. In these regions, $\mathrm{NaCl}$ crystallites a few micrometer wide and with a cubic or cubo-octahedral shape due to exposed $\{100\}$ or partially $\{111\}$ faces were observed (Fig. 11D). Therefore, we suggest that the halite formation contributing to the aforementioned extensions and the deposits in the last-mentioned regions proceeded after the precipitation of the principal $\mathrm{NaCl}$ branch in the ultimate phase of the droplet drying process.

\section{Effect of collagen}

The final investigation focused on the precipitates formed when drying droplets containing $5 \mathrm{mg} / \mathrm{mL}$ collagen as a starting concentration. The findings obtained by light microscopy (see Fig. 13), SEM (see Fig. 14), and EDX mapping (see Fig. 15) revealed the formation of polycrystalline crosswise dendrites extending from the initial contact line towards the sample center. Similarly, orthogonal dendrites with straight branches of sodium chloride were observed when grown in a thin gel matrix made of gelatin 


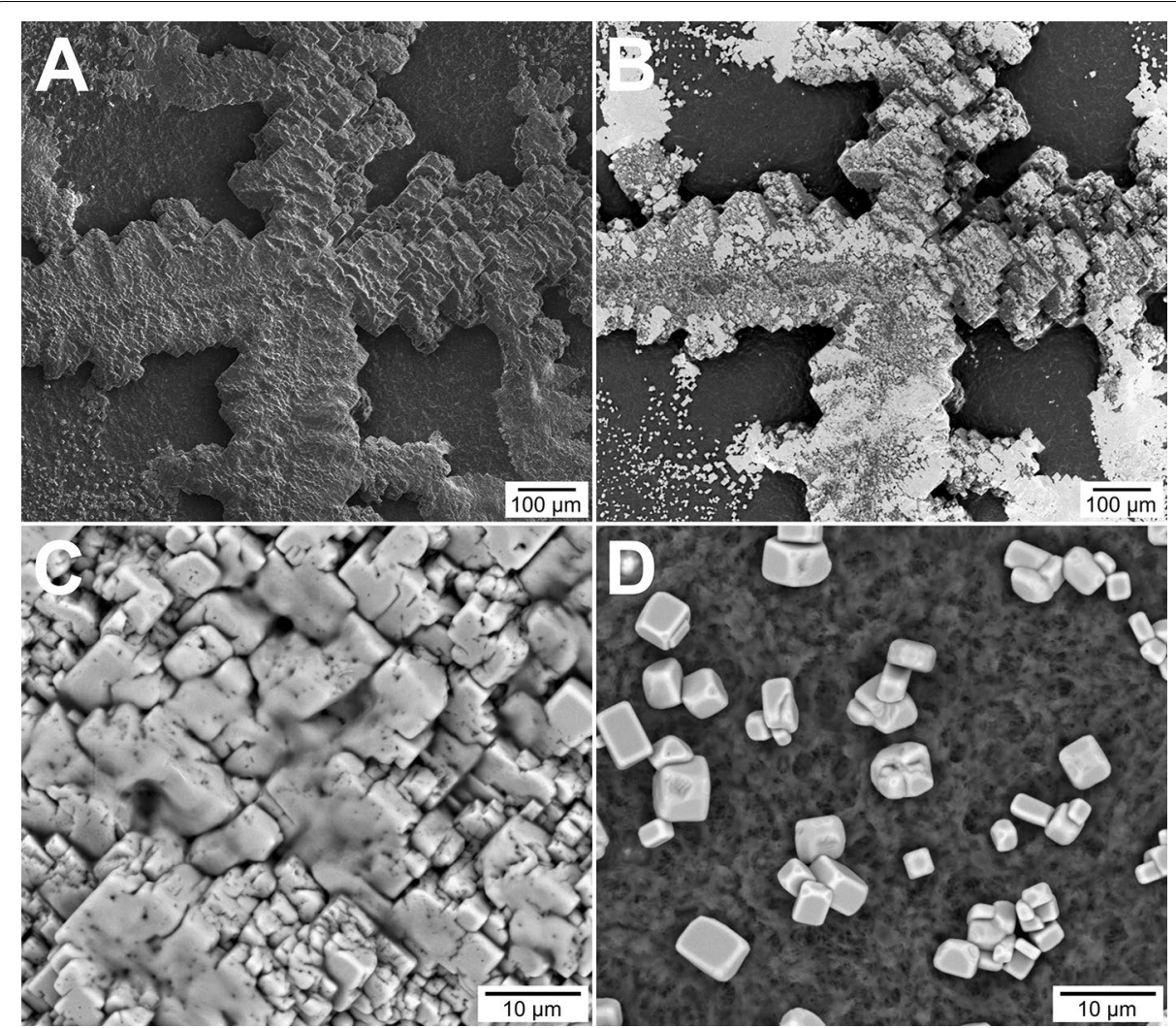

Fig. 11 SEM images obtained after drying a droplet of a solution containing $375 \mathrm{mM} \mathrm{NaCl}, 5 \mathrm{mM}$ Tris- $\mathrm{HCl}$ buffer and $5 \mathrm{mg} / \mathrm{mL}$ fibrinogen: details on top and around $\mathrm{NaCl}$ dendrites, as contrasted detecting (A) secondary (SE) or (B) back-scattered electrons (BSE). (C) BSE-SEM views of the dendrite surface, (D) BSE-SEM images of the region away from the dendrites

[11], a collagen hydrolysate, at mass concentration ratios [gelatin] $/[\mathrm{NaCl}]$ of around 0.5 ; meanwhile, we used a mass concentration ratio of 0.23 in the Tris buffer. In the dendrites, the sizes of the elevated halite grains on top of the approximately $0.2 \mathrm{~mm}$ high central $\mathrm{NaCl}$ crystallite ranged from 30 to $50 \mu \mathrm{m}$ (see Fig. 14A-C), meaning they were significantly bigger than the ones obtained in the presence of fibrinogen.

\section{Effects of distinct proteins in direct comparison}

By comparing the microscopic findings for the structure and arrangement of halite crystallites formed during the drying of droplets containing aqueous formulations buffered with $5 \mathrm{mM}$ Tris and a given $\mathrm{NaCl}$ concentration of $22 \mathrm{mg} / \mathrm{mL}$ we found that adding an initial $5 \mathrm{mg} / \mathrm{mL}$ concentration of a protein chosen among BSA, fibrinogen or collagen significantly and specifically changed the obtained drying pattern on goldcoated glass slides. On the one hand, the addition of the globular protein BSA did not strongly affect the overall drying pattern and-as also observed in the absence of proteins-still gave rise to the formation of approximately $1 \mathrm{~mm}$ wide halite crystals with a clear and transparent optical appearance. However, in the presence of BSA, the crystal shape was not tabular as in the absence of any protein, but hoppered. On the 


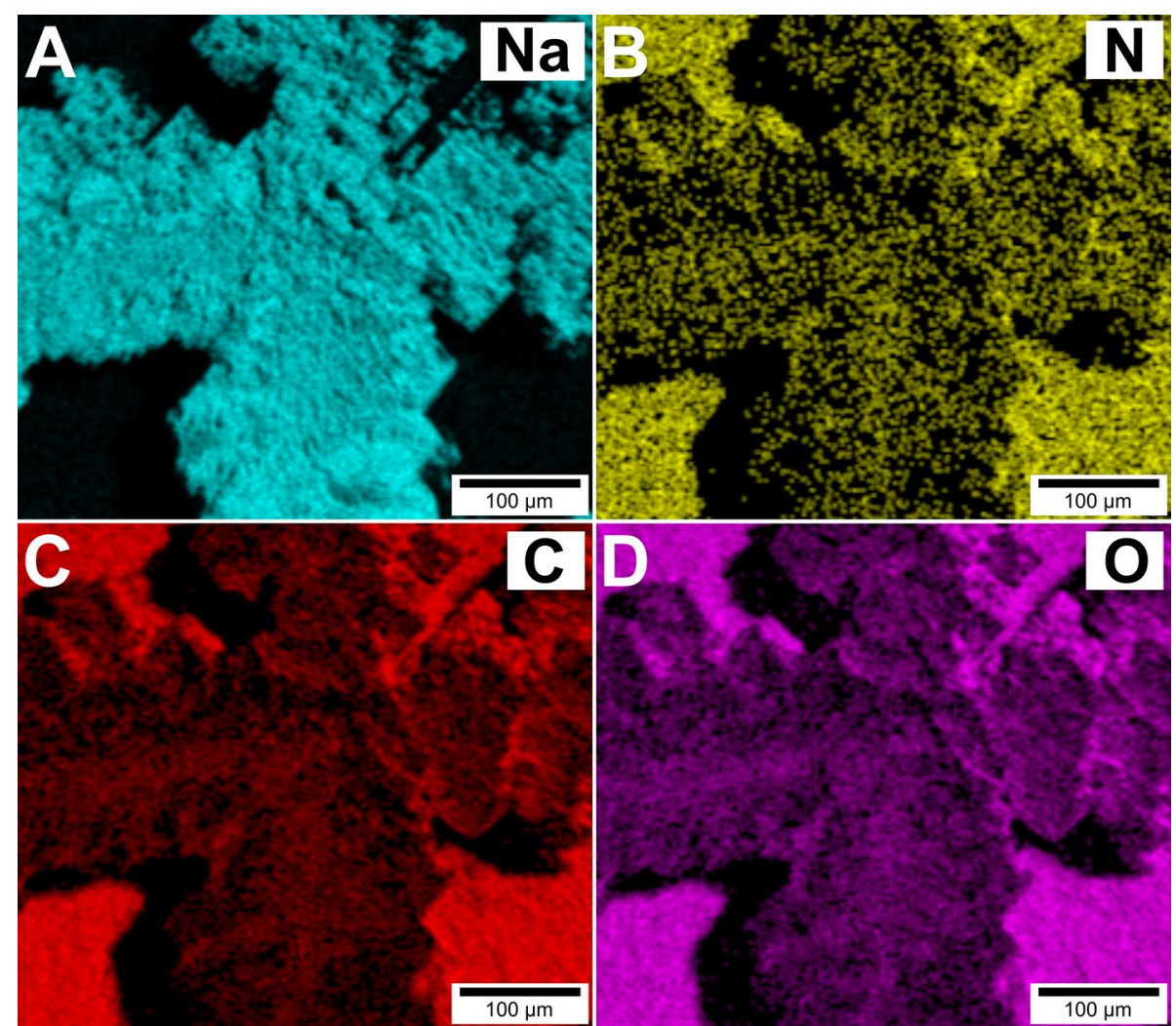

Fig. 12 EDX map false color representations in the region on top and around a crosswise $\mathrm{NaCl}$ dendrite as obtained after drying a droplet of a solution containing $375 \mathrm{mM} \mathrm{NaCl}, 5 \mathrm{mM}$ Tris-HCl buffer and $5 \mathrm{mg} / \mathrm{mL}$ BSA: (A) Na map, (B) N map, (C) C map, and (D) O map

other hand, adding the fibrillar proteins fibrinogen or collagen resulted in the formation of polycrystalline dendritic $\mathrm{NaCl}$ deposits with halite grain sizes clearly below $0.1 \mathrm{~mm}$ and an opaque optical appearance. Hence, the very nature of a specific protein and its complex interactions with the co-solutes $\mathrm{NaCl}$ and Tris significantly govern the formation of halite grain boundaries. We suppose that in the case of fibrinogen and collagen, the resulting salt crystals are shaped by persisting interphases between the salt and the circumjacent aqueous formulation, impedinge an Ostwald ripening of neighboring halite crystallite grains over distances exceeding $0.1 \mathrm{~mm}$. Facilitating such longer-range transport in the liquid phase or even water monolayers [61] would be expected to result in a reduction of the number of smaller sodium chloride deposits for the benefit of bigger crystals with an energetically more favorable faceting of their habits. We thus rather infer that the rate of solute transport may be affected by the viscosity of the concentrated mobile phase, while the restructuring of the halite grain surfaces by the loss and gain of growth units may be influenced by protein-containing films and adsorbates. In this way, both the transport and the surface-related reaction term contributing to the Damköhler number characterizing the dynamics between the stationary and mobile phases will depend on the presence of a specific protein. 


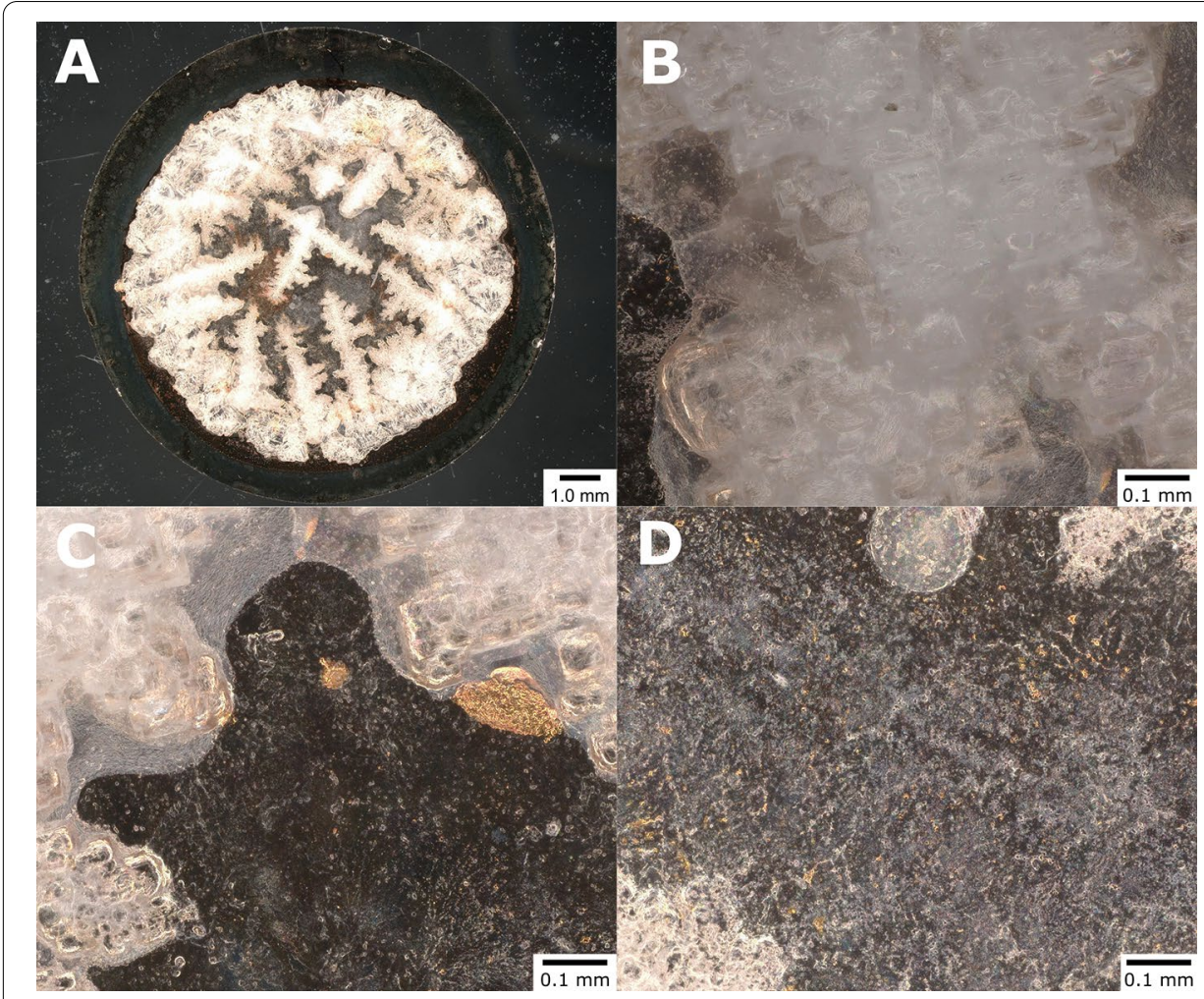

Fig. 13 Light microscopy of $\mathrm{NaCl}$ crystals formed after drying a droplet of a solution containing $375 \mathrm{mM}$ $\mathrm{NaCl}, 5 \mathrm{mM}$ Tris-HCl buffer, $375 \mathrm{mM}$ acetic acid and $5 \mathrm{mg} / \mathrm{mL}$ collagen. (A) Overview image of the sample ( $\times 20$ magnification), (B) detail of an "on salt" region ( $\times 300$ magnification), (C) detail of the halo region $(\times 200$ magnification) and (D) detail of the region away from the salt ( $\times 500$ magnification)

Based on our findings, we suggest that the specific protein- $\mathrm{NaCl}$ interactions are guided by the behaviour of the respective protein at the salt/liquid interphase, with the effect of collagen being rather more similar to that of fibrinogen than to that of BSA. Globular proteins on the one hand, and fibrous proteins, on the other hand, not only differ in the principles of their topology but also in the relative abundance of apolar and polar side chains in the amino acids constituting these proteins and the molecular flexibility [62]. For example, Cacace et al. highlighted that at $\mathrm{pH} 7$ in the hydrated state the surface tension of human serum albumin (HSA) features a lower contribution from apolar Lifschitz-van der Waals interactions and a higher share of polar electron acceptor and electron donor potentials than the surface tension of fibrinogen. Therefore, we hypothesize that the specific interactions between a protein and the halite surface significantly influence the observed drying pattern. In detail, the reaction-related contributions to adhesion development within the frame of the macrokinetic approach based on a characteristic Damköhler number may be manifold. The process steps governing the formation of the interphase between the growing solid phase, e.g. salt crystals or solidified protein, and the highly viscous saline aqueous jelly phase containing protein may be related to two principal reaction-type binding events [63]: firstly, the often exothermic binding between cations or anions and the solid phase and, secondly, the entropy-driven and often endothermic water 


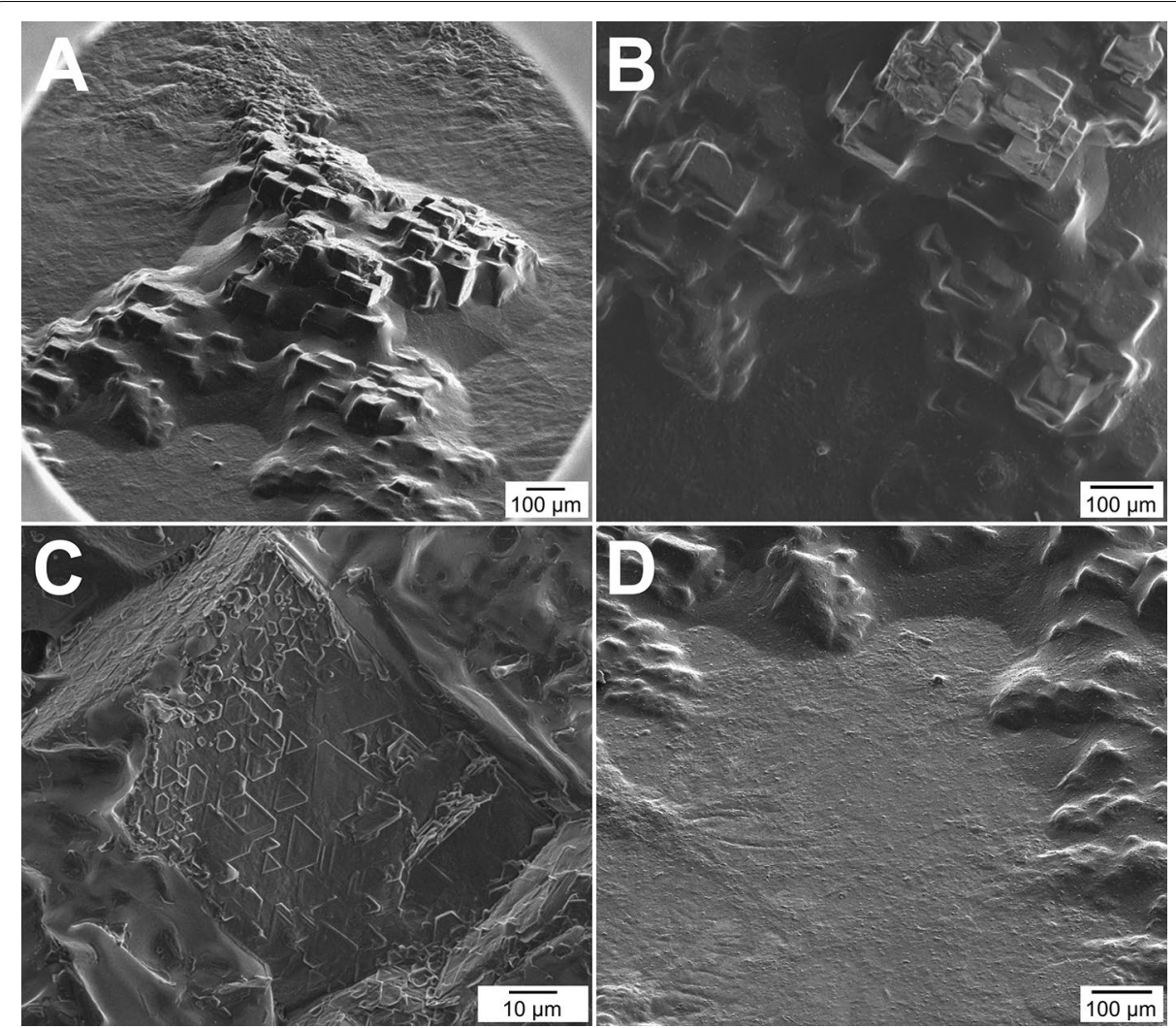

Fig. 14 SEM images of $\mathrm{NaCl}$ dendrites formed after drying a droplet of a solution containing $375 \mathrm{mM}$ $\mathrm{NaCl}, 5 \mathrm{mM}$ Tris- $\mathrm{HCl}$ buffer, $375 \mathrm{mM}$ acetic acid and $5 \mathrm{mg} / \mathrm{mL}$ collagen. (A) Shows a tilted (52 ) view of $\mathrm{NaCl}$ dendrites ("on salt" region), (B), (C): top-view details of different crystallites, and (D) region between dendritic $\mathrm{NaCl}$ crystals

replacement-e.g. upon dehydration of inorganic or organic moieties-in interphases, such as at highly dynamic salt crystal or protein interfaces in contact with the fluid environment.

In this way, acquiring knowledge on the formation of hybrid or composite materials in droplets of saturated aqueous solutions composed of several co-solutes in environments involving salts and proteins may be inspired by nature and promote medical, pharmaceutical or technological innovation. As highlighted by Lohse and Zhang [64], the spatiotemporal development of multicomponent fluid dynamical systems out of equilibrium is governed by concentration gradients inducing a transport concurring with phase transitions. These complex and interwoven phenomena and the challenges and opportunities related to them may be dealt with by the experimental, numerical and methodical tools and procedures provided by implementing the digital transformation not only in industry but also in research and development. Hence, exploring and designing the spatiotemporal evolution of adhesion is a topic that shows great promise in profiting from advanced materials modelling. 


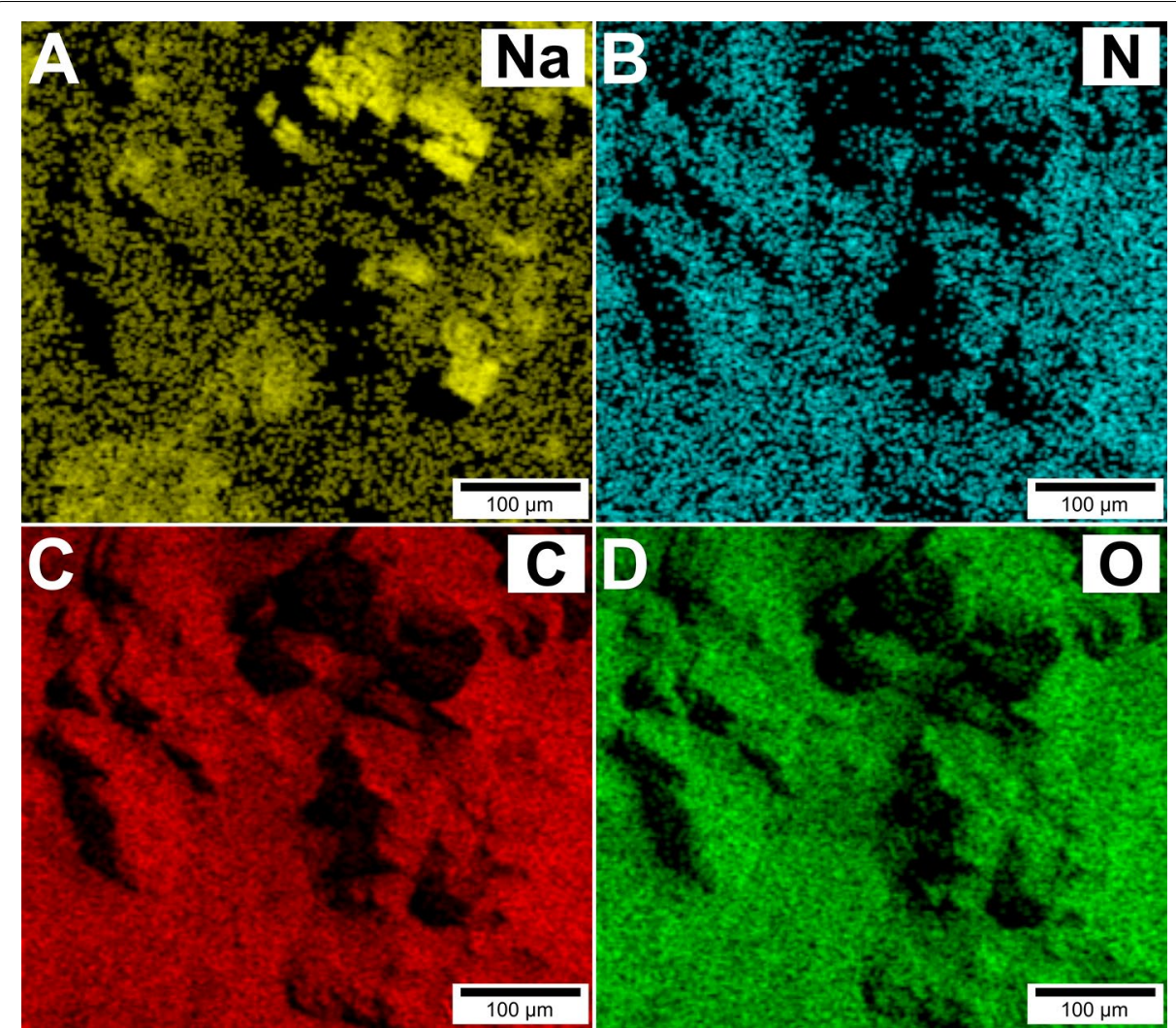

Fig. 15 EDX map false color representations in the region $375 \mathrm{mM} \mathrm{NaCl}, 5 \mathrm{mM}$ Tris-HCl buffer, $375 \mathrm{mM}$ acetic acid and $5 \mathrm{mg} / \mathrm{mL}$ collagen: (A) Na map, (B) $\mathrm{N}$ map, (C) C map, and (D) O map

\section{Conclusions}

In this study on the drying patterns formed from aqueous saline formulations, we found that the $\mathrm{NaCl}$ crystal arrangements and morphologies varied with the composition of the initial solution. Depending on the type of the protein chosen, among BSA, fibrinogen and collagen, the halite deposits predominantly exhibited cubic or polycrystalline dendritic structures. Based on these results, we hypothesize that the process steps in the formation of the interphase between the growing solid phase and the highly viscous saline aqueous jelly phase containing protein govern not only the material transport in the liquid but also the material exchange between solid and liquid phases. In the future, the synthesis of bio-inspired, protein-based composite materials will benefit immensely from understanding fundamental solid-liquid phase interactions to successively tailor these scale-comprehensive dynamic processes.

\section{Abbreviations}

BSA: Bovine serum albumin; Tris: Tris(hydroxymethyl)aminomethane; Da: Damköhler number; EDX: Energy dispersive $X$-ray analysis; SEM: Scanning electron microscopy.

\section{Acknowledgements}

The authors thankfully acknowledge the peers for in-depth assessment and comments on the manuscript and Andreas Volkmann for technically supporting light microscopic investigations. 


\section{Authors' contributions}

StS prepared the samples and set up the light microscopy experiments supported by KB and VCB, and contributed to the lay-out, drafting and formatting of the article; KB and VCB also contributed to the discussion of microscopic characterization; KT performed the SEM and EDX measurements and contributed to the discussion of microscopic characterization; WLC and MN took part in defining and setting up the experiments, discussing and merging the obtained data and in drafting the manuscript; IG, PS and SD took part in defining and setting up the experiments based on emerging material design challenges; DB contributed in planning the conceptual approach for joint research and in discussing results and drafting the manuscript. All authors read and approved the final manuscript.

\section{Funding}

Open Access funding enabled and organized by Projekt DEAL. D.B.: Emmy Noether program of the German Research Council (DFG), Grant Number 267326782. St.S.: Fraunhofer TALENTA start program.

\section{Availability of data and materials}

The datasets used and/or analyzed during the current study are available from the corresponding author upon reasonable request.

\section{Declarations}

\section{Competing interests}

The authors declare that they have no competing interests.

\section{Author details}

${ }^{1}$ Fraunhofer Institute for Manufacturing Technology and Advanced Materials IFAM, Wiener Straße 12, 28359 Bremen, Germany. ${ }^{2}$ Institute for Biophysics, University of Bremen, Otto-Hahn-Allee 1, 28359 Bremen, Germany. ${ }^{3}$ Hochschule Bremen, City University of Applied Sciences, Neustadtswall 30, 28199 Bremen, Germany. ${ }^{4}$ Purenum GmbH, Fahrenheitstraße 1, 28359 Bremen, Germany. ${ }^{5}$ MAPEX Center for Materials and Processes, University of Bremen, 28359 Bremen, Germany. ${ }^{6}$ Department Adhesion and Interface Research, Fraunhofer Institute for Manufacturing Technology and Advanced Materials, Wiener Straße 12, 28359 Bremen, Germany.

Received: 20 August 2021 Accepted: 18 October 2021

Published online: 03 November 2021

\section{References}

1. Bruckschen P, Neuser RD, Richter DK (1992) Cement stratigraphy in Triassic and Jurassic limestones of the Weserbergland (northwestern Germany). Sediment Geol 81:195-214

2. Arakaki A, Shimizu K, Oda M, Sakamoto T, Nishimura T, Kato T (2015) Biomineralization-inspired synthesis of functional organic/inorganic hybrid materials: organic molecular control of self-organization of hybrids. Org Biomol Chem R Soc Chem 13:974-989

3. Hu X, Cebe P, Weiss AS, Omenetto F, Kaplan DL (2012) Protein-based composite materials. Mater Today 15:208215. https://doi.org/10.1016/S1369-7021(12)70091-3

4. Yin J, Chen JC, Wu Q, Chen GQ (2015) Halophiles, coming stars for industrial biotechnology. Biotechnol Adv 33(7):1433-1442

5. Ma Y, Galinski EA, Grant WD, Oren A, Ventosa A (2010) Halophiles 2010: life in saline environments. Appl Environ Microbiol 76:6971-6981

6. DasSarma S, DasSarma P (2017) Halophiles. eLS. Wiley, Chichester, pp 1-13. https://doi.org/10.1002/9780470015 902.a0000394.pub3

7. Pasteris JD, Freeman JJ, Wopenka B, Qi K, Ma Q, Wooley KL (2006) With a grain of salt: what halite has to offer to discussions on the origin of life. Astrobiology 6:625-643

8. Lopez-Cortes A, Ochoa J, Vazquez-Duhalt R (1994) Participation of halobacteria in crystal formation and the crystallization rate of $\mathrm{NaCl}$. Geomicrobiol J 12:69-80. https://doi.org/10.1080/01490459409377973

9. Zhou M, Yi RJ, Gu Y, Zou J, Guo X (2019) Characterization and evaluation of synthesized ammonia triethyl amide (ATEA) for removing sodium chloride deposition. J Pet Sci Eng 179:136-142. https://doi.org/10.1016/j.petrol. 2019.04.005

10. Dutta Choudhury M, Dutta T, Tarafdar S (2015) Growth kinetics of NaCl crystals in a drying drop of gelatin: transition from faceted to dendritic growth. Soft Matter R Soc Chem 11:6938-6947

11. Goto M, Oaki Y, Imai H (2016) Dendritic growth of $\mathrm{NaCl}$ crystals in a gel matrix: variation of branching and control of bending. Cryst Growth Des 16:4278-4284. https://doi.org/10.1021/acs.cgd.6b00323

12. Pramanik R, Asplin JR, Jackson ME, Williams JC (2008) Protein content of human apatite and brushite kidney stones: significant correlation with morphologic measures. Urol Res 36:251-258

13. Kovacevic L, Lu H, Kovacevic N, Lakshmanan Y (2020) Effect of bisphosphonates on the crystallization of stoneforming salts in synthetic urine. Investig Clin Urol 61:310-315

14. Dumetz AC, Snellinger-O'Brien AM, Kaler EW, Lenhoff AM (2007) Patterns of protein-protein interactions in salt solutions and implications for protein crystallization. Protein Sci 16:1867-1877

15. Hyde AM, Zultanski SL, Waldman JH, Zhong YL, Shevlin M, Peng F (2017) General principles and strategies for salting-out informed by the Hofmeister series. Org Process Res Dev 21(9):1355-1370

16. Shih Y-C, Prausnitz JM, Blanch HW (1992) Some characteristics of protein precipitation by salts. Biotechnol Bioeng 40:1155-1164 
17. Yang X, Lu J, Wang XJ, Ching CB (2008) Effect of sodium chloride on the nucleation and polymorphic transformation of glycine. J Cryst Growth 310:604-611

18. Takahashi D, Nishimoto E, Murase T, Yamashita S (2008) Protein-protein interaction on lysozyme crystallization revealed by rotational diffusion analysis. Biophys J 94:4484-4492. https://doi.org/10.1529/biophysj.107.111872

19. Kang ZL, Zhang XH, Li X, Song ZJ, Ma HJ, Lu F et al (2020) The effects of sodium chloride on proteins aggregation, conformation and gel properties of pork myofibrillar protein running head: relationship aggregation, conformation and gel properties. J Food Sci Technol. https://doi.org/10.1007/s13197-020-04736-4

20. Gronau G, Qin Z, Buehler MJ (2013) Effect of sodium chloride on the structure and stability of spider silk's $\mathrm{N}$-terminal protein domain. Biomater Sci 1:276-284

21. Kadler KE, Holmes DF, Trotter JA, Chapman JA (1996) Review article: collagen fibril formation Karl. Biochem J $11: 1-11$

22. Stamboroski S, Joshi A, Noeske PL-M, Köppen S, Brüggemann D (2021) Principles of fibrinogen fiber assembly in vitro. Macromol Biosci 21(5):2000412

23. Nürnberger S, Rentenberger C, Thiel K, Schädl B, Grunwald I, Ponomarev I et al (2017) Giant crystals inside mitochondria of equine chondrocytes. Histochem Cell Biol 147:635-649

24. Corrales-Urena YR, Sanchez A, Pereira R, Rischka K, Kowalik T, Vega-Baudrit J (2017) Extracellular micro and nanostructures forming the velvet worm solidified adhesive secretion. Mater Res Express 4:125013

25. Gaede-Koehler A, Kreider A, Canfield P, Kleemeier M, Grunwald I (2012) Direct measurement of the thermal hysteresis of antifreeze proteins (AFPs) using sonocrystallization. Anal Chem 84:10229-10235. https://doi.org/10.1021/ ac301946w

26. He Z, Wu C, Hua M, Wu S, Wu D, Zhu X et al (2020) Bioinspired multifunctional anti-icing hydrogel. Matter Cell Press 2:723-734

27. Rathi S, Saka R, Domb AJ, Khan W (2019) Protein-based bioadhesives and bioglues. Polym Adv Technol 30:217-234. https://doi.org/10.1002/pat.4465

28. Richter K, Grunwald I, von Byern J (2018) Bioadhesives. Handbook of adhesive technology, 2nd edn. Springer International Publishing, Cham, pp 1597-640. https://doi.org/10.1007/978-3-319-55411-2_53

29. Deng Y, Ediriwickrema A, Yang F, Lewis J, Girardi M, Saltzman WM (2015) A sunblock based on bioadhesive nanoparticles. Nat Mater 14:1278-1285

30. Cavalcanti WL, Noeske PL-M (2014) Investigating dynamic interactions by multi-scale modelling: from theory to applications. Chem Model 11:175-200. https://doi.org/10.1039/9781782620112-00175

31. Raetzke K, Shaikh MQ, Faupel F, Noeske PLM (2010) Shelf stability of reactive adhesive formulations: a case study for dicyandiamide-cured epoxy systems. Int J Adhes Adhes 30:105-110. https://doi.org/10.1016/j.ijadhadh.2009.09.004

32. Sanchez-Vila X, Dentz M, Donado LD (2007) Transport-controlled reaction rates under local non-equilibrium conditions. Geophys Res Lett 34:1-5

33. Yu F, Hunt AG (2017) Damkö hler number input to transport-limited chemical weathering calculations. https:// pubs.acs.org/sharingguidelines. Accessed 5 Aug 2021

34. Naillon A, Joseph P, Prat M (2017) Sodium chloride precipitation reaction coefficient from crystallization experiment in a microfluidic device. J Cryst Growth 463:201-210

35. Desarnaud J, Derluyn H, Carmeliet J, Bonn D, Shahidzadeh N (2018) Hopper growth of salt crystals. J Phys Chem Lett 9:2961-2966. https://doi.org/10.1021/acs.jpclett.8b01082

36. Yang Z, Zhang J, Zhang L, Fu B, Tao P, Song C et al (2020) Self-assembly in hopper-shaped crystals. Adv Funct Mater 30:1-26

37. McBride SA, Skye R, Varanasi KK (2020) Differences between colloidal and crystalline evaporative deposits. Langmuir 36:11732-11741. https://doi.org/10.1021/acs.langmuir.0c01139

38. Huang L, Zhang Z, Guo M, Pan C, Huang Z, Jin J et al (2021) Biomimetic hydrogels loaded with nanofibers mediate sustained release of pDNA and promote in situ bone regeneration. Macromol Biosci. https://doi.org/10.1002/mabi. 202000393

39. Perez FMU, Corrales Ureña YR, Rischka K, Cavalcanti WL, Noeske PLM, Safari AA et al (2019) Bio-interfactants as double-sided tapes for graphene oxide. Nanoscale 11:4236-4247. https://doi.org/10.1039/c8nr08607a

40. Raucci MG, Guarino V, Ambrosio L (2010) Hybrid composite scaffolds prepared by sol-gel method for bone regeneration. Compos SciTechnol 70:1861-1868

41. Zhao H, Yang Z, Guo L (2018) Nacre-inspired composites with different macroscopic dimensions: strategies for improved mechanical performance and applications. NPG Asia Mater 10:1-22. https://doi.org/10.1038/ s41427-018-0009-6

42. Rillig MC (2005) A connection between fungal hydrophobins and soil water repellency? Pedobiologia (Jena) 49:395-399

43. Berger BW, Sallada ND (2019) Hydrophobins: multifunctional biosurfactants for interface engineering. J Biol Eng. https://doi.org/10.1186/s13036-018-0136-1

44. Montoya G, Lopez K, Arenas J, Zamora C, Hoz L, Romo E et al (2020) Nucleation and growth inhibition of biological minerals by cementum attachment protein-derived peptide (CAP-pi). J Pept Sci. https://doi.org/10.1002/psc.3282

45. Mao J, Nierop KGJ, Dekker SC, Dekker LW, Chen B (2019) Understanding the mechanisms of soil water repellency from nanoscale to ecosystem scale: a review. J Soils Sediments. https://doi.org/10.1007/s11368-018-2195-9

46. Nguyen PH, Ramamoorthy A, Sahoo BR, Zheng J, Faller P, Straub JE et al (2021) Amyloid oligomers: a joint experimental/computational perspective on Alzheimer's disease, Parkinson's disease, Type II diabetes, and amyotrophic lateral sclerosis. Chem Rev 121:2545-2647. https://doi.org/10.1021/acs.chemrev.0c01122

47. Cavalcanti W, Santos M, Figueiredo W (2004) Growth model with a finite number of orientations on a linear substrate. Phys Rev E 69:021608. https://doi.org/10.1103/PhysRevE.69.021608

48. Horsch MT, Niethammer C, Boccardo G, Carbone P, Chiacchiera S, Chiricotto M et al (2020) Semantic interoperability and characterization of data provenance in computational molecular engineering. J Chem Eng Data 65:1313-1329. https://doi.org/10.1021/acs.jced.9b00739 
49. Stapelfeldt K, Stamboroski S, Mednikova P, Brüggemann D (2019) Fabrication of 3D-nanofibrous fibrinogen scaffolds using salt-induced self assembly. Biofabrication 11:025010. https://doi.org/10.1088/1758-5090/ab0681

50. Stapelfeldt K, Stamboroski S, Walter I, Suter N, Kowalik T, Michaelis M et al (2019) Controlling the multiscale structure of nanofibrous fibrinogen scaffolds for wound healing. Nano Lett 49:1-15

51. Suter N, Joshi A, Wunsch T, Graupner N, Stapelfeldt K, Radmacher M et al (2021) Self-assembled fibrinogen nanofibers support fibroblast adhesion and prevent E. coli infiltration. Mater Sci Eng C 126:112156

52. Stamboroski S, Boateng K, Lierath J, Kowalik T, Thiel K, Köppen S et al (2021) Influence of divalent metal ions on the precipitation of the plasma protein fibrinogen. Biomacromolecules. https://doi.org/10.1021/acs.biomac.1 00930

53. Dutta D, Markhoff J, Suter N, Rezwan K, Brüggemann D (2021) Effect of collagen nanofibers and silanization on the interaction of HaCaT keratinocytes and 3T3 fibroblasts with alumina nanopores. ACS Appl Bio Mater 4:1852-1862

54. Suter N, Stebel S, Rianna C, Radmacher M, Brüggemann D (2021) Spatial patterning of nanofibrous collagen scaffolds modulates fibroblast morphology. Biofabrication 13:015007-015018

55. Saveleva MS, Eftekhari K, Abalymov A, Douglas TEL, Volodkin D, Parakhonskiy BV et al (2019) Hierarchy of hybrid materials-the place of inorganics-in-organics in it, their composition and applications. Front Chem 7:1-21

56. Rodrigues M, Kosaric N, Bonham CA, Gurtner GC (2019) Wound healing: a cellular perspective. Physiol Rev 99:665-706

57. Kamasa P, Bokor M, Pyda M, Tompa K (2007) DSC approach for the investigation of mobile water fractions in aqueous solutions of $\mathrm{NaCl}$ and Tris buffer. Thermochim Acta 464:29-34

58. Giri A, Choudhury MD, Dutta T, Tarafdar S (2013) Experiment and simulation of multifractal growth of crystalline $\mathrm{NaCl}$ aggregates in aqueous gelatin medium. Colloids Surf A Physicochem Eng Asp 432:127-131

59. Shahidzadeh N, Schut MFL, Desarnaud J, Prat M, Bonn D (2015) Salt stains from evaporating droplets. Sci Rep 5:1-9

60. Taha M, Lee M-J (2010) Interactions of TRIS [tris(hydroxymethyl)aminomethane] and related buffers with peptide backbone: thermodynamic characterization. Phys Chem Chem Phys 12:12840

61. Oliva-Ramirez M, Macías-Montero M, Borras A, González-Elipe AR (2016) Ripening and recrystallization of $\mathrm{NaCl}$ nanocrystals in humid conditions. RSC Adv 6:3778-3782

62. Cacace MG, Landau EM, Ramsden JJ (1997) The Hofmeister series: salt and solvent effectson interfacial phenomena. Q Rev Biophys 30:241-277

63. Darby SJ, Platts L, Daniel MS, Cowieson AJ, Falconer RJ (2017) An isothermal titration calorimetry study of phytate binding to lysozyme: a multisite electrostatic binding reaction. J Therm Anal Calorim 127:1201-1208

64. Lohse D, Zhang X (2020) Physicochemical hydrodynamics of droplets out of equilibrium. Nat Rev Phys 2:426-443

\section{Publisher's Note}

Springer Nature remains neutral with regard to jurisdictional claims in published maps and institutional affiliations.

\section{Submit your manuscript to a SpringerOpen ${ }^{\circ}$ journal and benefit from:}

- Convenient online submission

- Rigorous peer review

- Open access: articles freely available online

- High visibility within the field

- Retaining the copyright to your article

Submit your next manuscript at $\boldsymbol{\nabla}$ springeropen.com 